\title{
Synadenium grantii Hook f.: HPLC/QTOF-MS/MS TENTATIVE IDENTIFICATION OF THE PHYTOCONSTITUENTS, ANTIOXIDANT, ANTIMICROBIAL AND ANTIBIOFILM EVALUATION OF THE AERIAL PARTS
}

\author{
Asmaa S. Abd Elkarim ${ }^{1,}$, Amal H. Ahmed ${ }^{2}$, Hanan A.A. Taie ${ }^{3}$, Abdelbaset \\ M. Elgamal ${ }^{4}$, Mohammed Abu-Elghait ${ }^{5}$ and Samah Shabana ${ }^{6}$ \\ ${ }^{1}$ Chemistry of Tanning Materials and Leather Technology Department, National Research \\ Centre, 33 El Bohouth st. (former EL Tahrir st.)-Dokki-Giza-Egypt-P.O.12622 \\ ${ }^{2}$ Pharmacognosy Department, Faculty of Pharmacy, Al-azhar University, \\ 11884 Nasr City, Cairo, Egypt \\ ${ }^{3}$ Plant Biochemistry Department, Division of Agriculture and Biological Researches, National \\ Research Centre, 33 El-Bohouth St. (Former El-Tahrir St.), Dokki 12622, Giza, Egypt \\ ${ }^{4}$ Chemistry of Natural and Microbial Products Department, National Research Centre, 33 El \\ Bohouth st. (former EL Tahrir st.)-Dokki-Giza-Egypt-P.O.12622 \\ ${ }^{5}$ Department of Botany and Microbiology, Faculty of Science (Boys), Al-azhar University, \\ 11884 Nasr City, Cairo, Egypt \\ ${ }^{6}$ Faculty of Pharmaceutical Sciences and Drug Manufacturing, Misr University for Science and \\ Technology, MUST, $6^{\text {th }}$ October City, Egypt \\ Corresponding Author: asmaa_nrc@yahoo.com
}

\begin{abstract}
A rapid and simple effective technique HPLC/QTOF-MS/MS was developed to identify the constituents in synadenium grantii. This study aims to investigate antioxidant, antimicrobial and antibiofilm of aqueous methanol extract. Adequate conditions for extraction were employed and LC-MS/MS analysis was optimized in positive ion mode using full scan MS measurements and MS/MS fragmentations. The high concentration of S. grantiie extract exhibited a promising radical scavenging activity with all the tested antioxidant assays. It found to be $82.40 \pm 0.24$, $75.69 \pm 0.30$ and $90.27 \pm 0.16 \%$ using DPPH, Ion metal chelating and ABTS radical scavenging activity respectively, while it found to be $1.41 \pm 0.02$ Reducing power capacity and $2787 \pm 27.1 \mu$ molTrolox $/ 100 \mathrm{~g} \mathrm{D}$.W. (Ferric reducing power). The antioxidant activity of the extract was found to be as near as that of the synthetic BHA. Biofilm is a specific polymeric matrix produced by several bacterial species to make it more resistant against the immune system and diverse antibiotics. A total of 84 different metabolites were tentatively identified. The fragmentation characteristics are determined based on the exact mass information and $R_{f}$ values. It was found that flavonols, flavones, 1soflavone, chlorogenic acids, amino acids, stilbene and anthocyanins constitute mainly the phytoconstituents of the aerial parts. The biological examination exhibited excellent antioxidant activity using all tested assays and high antibiofilm activity against $S$. aureus with a reduction value $97.7 \%$ at $0.5 \mathrm{mg} / \mathrm{ml}$ without affecting bacterial growth which makes these compounds a promising agent for antimicrobial and antibiofilm against bacterial pathogens.

Keywords: Synadenium, LC/QTOF-MS/MS, Phytoconstituents, Antioxidant, Antimicrobial, Antibiofilm.
\end{abstract}

RASĀYAN J. Chem., Vol. 14, No.2, 2021

\section{INTRODUCTION}

Synadenium grantii Hook f. is a member of the Euphorbiaceae family, which includes over 300 genera and 8900 species, several of which are used in traditional medicine to treat diseases such as peptic ulcers, cancer and other health issues. Among them, Synadenium, is a small euphorbiaceous genus that contains nineteen species. This genus was found to be rich in various classes of bioactive constituents as flavonoids, saponins and diterpenes. ${ }^{1}$ To avoid tedious and long time-consuming classical methods of 
RASĀYAN J. Chem.

Vol. 14 | No. 2 |811-828| April - June | 2021

chromatographic separation for most major known compounds, hyphenation of HPLC with highresolution QTOF-MS/MS has successfully enabled us for rapid identification of a large number of minor constituents. This technique proves accurately the exact mass, formulae and differentiates between the isomeric compounds following their different $R_{t}$-values, MS/MS fragmentation trends and molecular formulae. ${ }^{2}$ There is a growing tendency in comparing the phytochemical constituents isolated from plants and their pharmacological actions. ${ }^{3}$ This due to the effective pharmacological activities, economic viability and low toxicity, the therapeutic properties of plants have been examined in the light of recent systematic developments throughout the world. According to pharmacological studies, herbal extracts contain important nutrients as well as a variety of bioactive compounds with antioxidant properties, such as flavonoids, phenolics, sterols, alkaloids, carotenoids, and glucosinolates. ${ }^{4,5}$ The present study deals with the examination of the antioxidant, antimicrobial and antibiofilm of the aqueous methanol extract (AME). Biofilms are a specific structure produced by a wide range of bacterial species. It has a special interest in the medical field due to the antibiotic-resistant characteristic gained from these special formulations and the effect it on the medical devices and human direct contact substances especially catheter surfaces which make it difficult to removed. ${ }^{6,7}$ Natural products compound especially plant originated products area promise sources for combating this phenomenon. ${ }^{8}$ The antimicrobial and antibiofilm activities of (AME) against Gram-positive and Gram-negative bacterial strains were investigated in this research to exploring its specific biological activities, which may introduce new therapeutic agents against bacterial problems.

\section{Plant-based materials}

\section{EXPERIMENTAL}

The aerial parts of S. grantii were collected in November 2017 from National Research Centre (NRC) garden (Dokki, Cairo, Egypt). The plant was classified as a species by Dr. M. EL-Gibaly, Lecturer of Taxonomy and Consultant for Central Administration of Plantation and Environment. Avoucher sample (No: A79), where it was held was deposited at the chemistry of tanning materials and leather technology department. National Research Centre (NRC), Dokki, Cairo, Egypt.

\section{Chemicals}

Acetonitrile (Fisher, optima ${ }^{\circledR}$, LC/MS-grade; Fair Lawn, NJ, USA), DI-water further purified by Milli-Q Plus water purification system (Millipore Ltd., Bedford, MA, USA) and methanol HPLC (Merck, EMSURE $^{\circledR}$, analytical grade; Darmstadt, Germany).

2,2-Diphenyl-2-picrylhydrazyl(DPPH), potassium ferri-cyanide, Trolox, ferrozine, 2,2'-azinobis-3ethylbenzothiazoline-6-sulfonicacid (ABTS), 3-(2-pyridyl)-5,6-diphenyl-1,2,4-triazine-4',4"-disulfonic acid, potassium ferri-cyanide, butylated hydroxytoluene (BHT), $\mathrm{FeCl}_{2}$ and $\mathrm{FeCl}_{3}$ were purchased from Sigma Chemical Co. (St. Louis, MO, USA). All the other chemicals used including the solvents were of analytical grade.

\section{Equipment and Conditions}

Fragmentation analyses were performed using (Triple TOF 5600+). The mobile phases consisted of DIWater contains $0.1 \% \mathrm{FA}$ (formic acid), ammonium format buffer $\mathrm{pH}=8$ containing $1 \%$ methanol and 100 $\%$ acetonitrile, in-Line filter disks Pre column $(0.5 \mu \mathrm{m} \times 3.0 \mathrm{~mm}$, Phenomenex $)$, Xbridge C18 column $\left(3.5 \mu \mathrm{m}, 2.1 \times 50 \mathrm{~mm}\right.$, waters) and the column temperature was maintained at $40^{\circ} \mathrm{C}$, flow rate $0.3 \mathrm{ml} / \mathrm{min}$ and the scan type (Information Dependent Acquisition (IDA).

\section{Extraction Methods}

The air-dried aerial parts of $S$. grantii $\left(1.75 \mathrm{~kg}\right.$ ) were crushed and extracted with $70 \%$ (Aq) $\mathrm{CH}_{3} \mathrm{OH}$ by soaking at room temperature (Macération). A rotary evaporator was used to evaporate the solvent under vacuum at $50^{\circ} \mathrm{C}$. Then the residue (dry) was sequentially defatted and desalted by $\mathrm{CHCl}_{3}$ and $\mathrm{C}_{2} \mathrm{H}_{5} \mathrm{OH}$, respectively, by warming under reflux conditions. Thereafter, the residue was taken in methanol, affording a methanol-soluble portion (MSP) that yielded methanol extract of $150 \mathrm{~g}$. 
RASĀYAN J. Chem.

Vol. 14 | No. 2 |811-828| April - June | 2021

\section{Sample Preparation}

The mobile phase working solution (MP-WS) is made up of 50: 25: $25 \mathrm{v} / \mathrm{v}$ DI-Water-MethanolAcetonitrile. To a $50 \mathrm{mg}$ weighted sample, add $1 \mathrm{ml} \mathrm{MP-WS}$, vortex for 2 minutes, then ultra-sonicate for 10 minutes before centrifuging for 5 minutes at $10000 \mathrm{rpm}$. An amount of $20 \mu 1$ stock (50/ $1000 \mu \mathrm{l})$ was diluted in 1000 liter reconstitution solvent. Finally, a concentration of $1 \mu \mathrm{g} / \mu \mathrm{l}$ was injected. Inject $251 \mu \mathrm{l}$ of total extract and $25 \mu 1$ of MP-WS as a blank sample in positive mode.

\section{Data Processing}

Master View was used for feature peaks extraction from the total ion chromatogram (TIC) based on features that should have Signal-to-Noise greater than 5 (Non-targeted analysis). Features intensities of the sample-to-blank should be greater than 5. Marker View was used for feature annotation and removing isotopic peaks. MasterView was used again to identify peaks based on their fragments using the Build-in database and online database; RESPECT and MONA (Mass Bank of North America).

\section{Investigation of Antioxidant Activity}

Following a previously reported protocol. ${ }^{9}{ }^{10} \mathrm{DPPH}, \mathrm{ABTS}$ percentage, FRAP and reducing power values of the studied extract and compounds were calculated. ${ }^{11}$ Metal chelating activity assay was determined according to the previous protocol. ${ }^{12}$

\section{Antimicrobial Activity and MIC Determination}

The antimicrobial activity was calculated using microtiterplate (MTP) method in this analysis and inhibitory concentration at minimum (MIC) of (AM) extract against Gram-positive and negative bacteria in addition to Candida ATCC strains as the following; S.aureus ATCC 29213,Bacillus subtilis ATTC605, P.aeruginosa 9027, E. coli ATCC8739andC. albicans ATCC 10213according to the Clinical and Laboratory Standards Institute(CLSI) (2019). ${ }^{13}$ Briefly, (AM) extract was diluted in DMSO 5\% (final concentration), gradient concentrations of the compound $(6.0-0.3 \mathrm{mg} / \mathrm{ml} \mathrm{w} / \mathrm{v})$ were added to the MTP wells before adding $200 \mu 1$ of 1: $100 \mathrm{v} / \mathrm{v}$ of overnight cultures of the $S$. aureus and $P$. aeruginosain TSB inoculum size $5 \times 10^{5} \mathrm{CFU} / \mathrm{ml}$ and incubated with shacking $100 \mathrm{rpm}$ in $37^{\circ} \mathrm{C}$ for $24 \mathrm{~h}$. after incubation, plates were read in ELIZA reader (Tecan Elx800, USA) at $620 \mathrm{~nm}$ for detecting the growth turbidity. The MIC was calculated as the lowest concentration at which the compound prevented the growth of test species using TSB media as a negative monitor. All tests were performed in triplicate.

\section{Assay for Biofilm Inhibition}

The ability of (AME) to inhibit or prevent bacterial biofilm formation was assessed using a microtiter plate assay against established biofilm generating strains S. aureus ATCC 29213 and P. aeruginosa ATCC 9027. Sub-lethal concentrations of (AME) $(4.0-0.3 \mathrm{mg} / \mathrm{ml})$ were loaded in flat bottom MTP containing Tryptic Soy broth media (TSB) with $1 \%$ glucose. S. aureus and P. aeruginosa overnight cultures were diluted 1: 100 in TSB to produce $1 \times 105 \mathrm{CFU} / \mathrm{ml}$, and both plates were incubated at $37^{\circ} \mathrm{C}$ for 48 hours. The planktonic cells were transferred without disrupting the biofilm after the incubation time, and cell growth was measured at $620 \mathrm{~nm}$ using an ELIZA reader (Tecan Elx800, USA). To remove excess planktonic cells, the plates were washed three times with sterilized phosphate-buffered saline (PBS) pH 7.2, and then biofilm fixed with 2001 of 95 percent methanol for 10 minutes. The plates were incubated for $15 \mathrm{~min}$. at room temperature after adding crystal violet $(0.1 \% \mathrm{w} / \mathrm{v})$. Then, the crystal violet was removed, and the wells were gently washed with sterile distilled water to remove the excess of the stain. Finally, an inverted microscope (Olympus Ck40Japan) $\mathrm{x} 40$ was used to analyze and photograph the adhered biofilm bounded crystal violet, which was then eluted in acetic acid $(30 \%)$ and the absorbance measured at $540 \mathrm{~nm}$ using an ELIZA reader (Tecan, Elx800- USA). ${ }^{13}$ As a solvent monitor, wells containing a volume of $5 \%$ DMSO were used. The results of the treated wells were compared to the untreated control wells. Any of the experiments were completed three times. ${ }^{14}$

\section{Chemical Composition of Methanol-soluble Portion (MSP) \\ RESULTS AND DISCUSSION}

LC-MS/MS analysis of (MSP) prepared from $S$. grantii aerial parts enabled us to identify about 84 compounds belonging to different types of natural products. Depending on the structural information 
RASĀYAN J. Chem.

Vol. 14 | No. 2 |811-828| April - June | 2021

obtained from HPLC/QTOF-MS/MS data, particularly $[\mathrm{M}+\mathrm{H}]^{+}$ions, total ion current chromatogram (TIC) (Fig.-1). A total of 84 components were unambiguously identified including 27 flavonoids of 14 flavonol and 13 flavone $C$ - and/or $O$-hexosides nature (Fig.-2). In addition to 6 phenolic acids, 23 amino acid derivatives, 6 anthocyanin, one isoflavone, 2 terbin, 9 Hydrolysable tannins derivatives and 10 organic compounds derivatives were tentatively identified based on their fragments (Table-1). Most of them were reported in S. grantii for the first time.

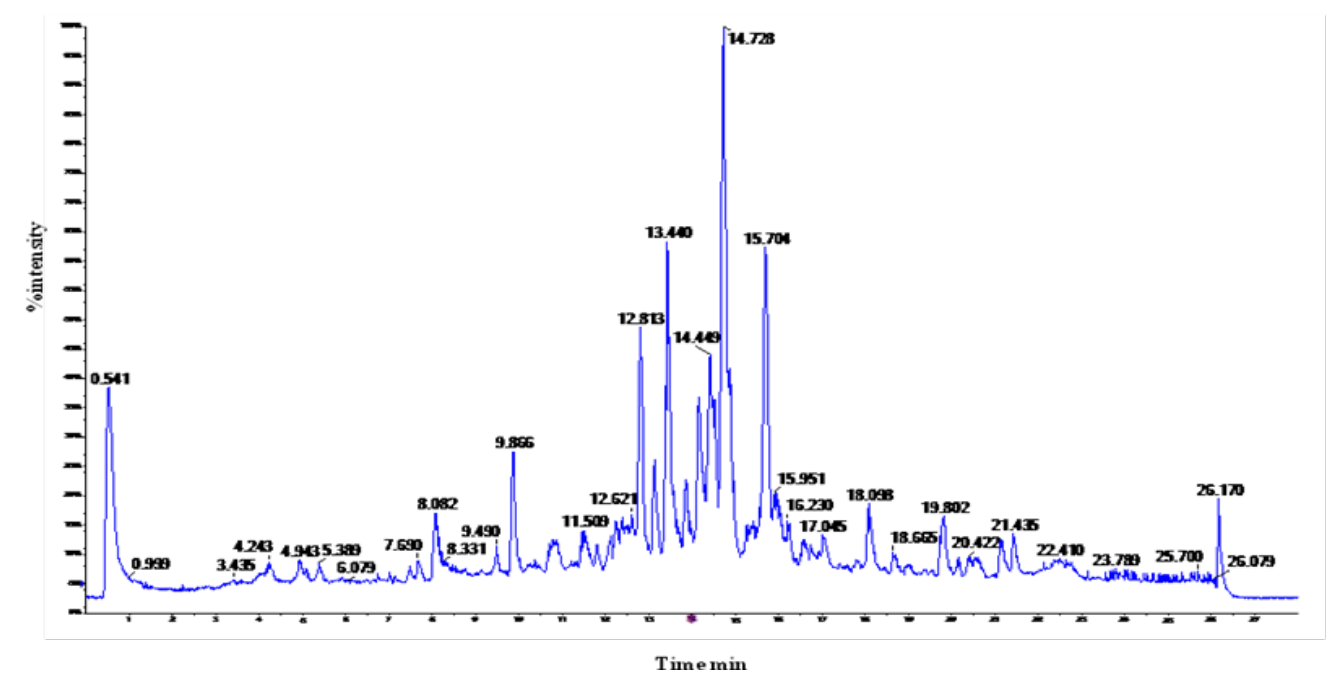

Fig.-1: LC-QTOF-MS/MS Total Ion Chromatogram (TIC) of AM Extract of Aerial Parts from S. grantii in Positive Mode.

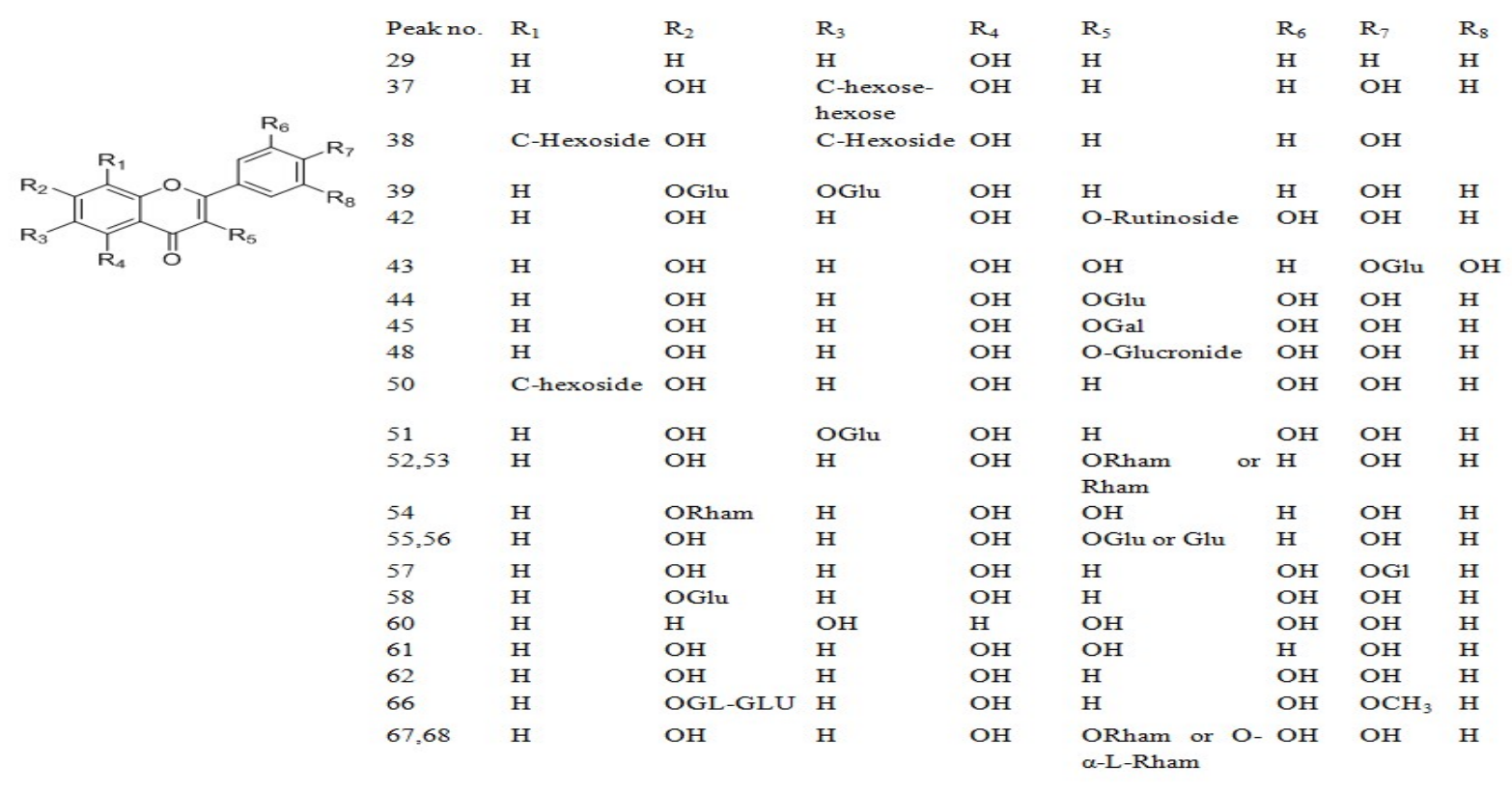<smiles>[H]/C=C\COc1c(O)cc2oc(=O)ccc2c1O</smiles>

(1)<smiles>CNC(C)C(=O)O</smiles>

(2)<smiles>CN(C)CC(=O)O</smiles>

(3) 
RASĀYAN J. Chem.

Vol. 14 | No. 2 |811-828| April - June | 2021<smiles>CN(C)CC(=O)O</smiles>

(4)<smiles>CCC(N)C(=O)O</smiles>

(8)<smiles>C[C@@H](O)[C@H](N)C(=O)O</smiles>

(11)<smiles>Nc1nc2[nH]cnc2c(=O)[nH]1</smiles>

(16)<smiles>COc1cc(O)cc(/C=C/c2ccc(O)cc2)c1</smiles>

(19)<smiles>NCCCC(=O)O</smiles>

(22)<smiles>CCC(C)[C@H](N)CC(=O)O</smiles>

$(25,26)$<smiles>CCC(N)C(=O)O</smiles>

$(5,6)$<smiles>NNC(CO)CC(=O)O</smiles>

(9)<smiles>N[C@@H](CCO)C(=O)O</smiles>

(13)<smiles>O=C(CCc1ccc(O)cc1)c1c(O)cc(O)cc1O</smiles>

(17)<smiles>C[C@H](O)[C@@H](N)C(=O)O</smiles>

(20)<smiles>Nc1nc2c(ncn2C2CCC3OCC2O3)c(=O)[nH]1</smiles>

(23)

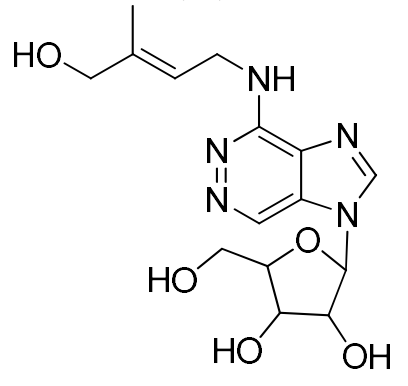

815<smiles>CC(C)(N)C(=O)O</smiles>

(7)<smiles>N[C@H](CO)CC(=O)O</smiles>

(10), (12), (14)<smiles>N[C@@H](CC(=O)O)C(=O)O</smiles>

(15)<smiles>NC1=NN=CC2C1N=CN2C1OC(CO)C(O)C1O</smiles>

(18)<smiles>CC(=O)N[C@@H]1C(C(O)C(O)CO)OC(O)(C(=O)O)C[C@@H]1O</smiles>

(21)<smiles></smiles>

(24)<smiles>NC(Cc1ccccc1)C(=O)O</smiles>

(28) 
RASĀYAN J. Chem.

Vol. 14 | No. 2 |811-828| April - June | 2021

(27)<smiles>O=c1cc(-c2ccccc2)oc2cc(O)ccc12</smiles>

(29)<smiles>O=C(C=Cc1ccc(O)c(O)c1)OC1(C(=O)O)CC(O)C(O)C(O)C1</smiles>

(32), (33)

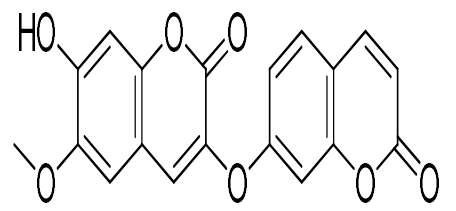

(30)<smiles>O=C(/C=C/c1ccc(O)c(O)c1)OC1C(C(=O)O)OC(O)C(O)C1O</smiles>

(31)<smiles>O=C(/C=C/c1ccc(O)c(O)c1)OC1CC(O)(C(=O)O)CC(O)C1O</smiles>

(34)<smiles>O=C(/C=C/c1ccc(O)c(O)c1)OC1C(O)CC(O)(C(=O)O)CC1O</smiles>

(35)<smiles>O=C(/C=C/c1ccc(O)c(O)c1)OC1CC(O)(C(=O)O)CC(O)C1O</smiles>

(36)<smiles>CC(C)Oc1ccc2occ(-c3ccccc3)c(=O)c2c1</smiles>

(40)

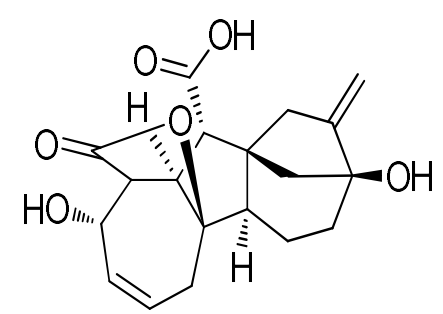

(49)

(47)<smiles>COc1ccccc1CC(Cc1nc2ccccc2[nH]1)c1nc2ccccc2[nH]1</smiles>

(65)

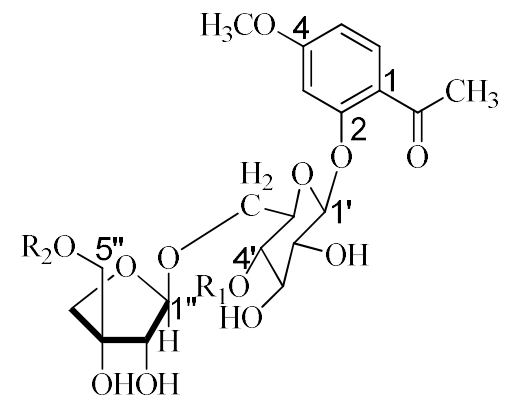

Sufftuticoside(B)

$\mathrm{R}_{1}=$ galloyl, $\mathrm{R}_{2}=\mathrm{H}$<smiles>COc1cccc2c[nH]c(CC(=NOS(=O)(=O)O)OC3OC(CO)C(O)C(O)C3O)c12</smiles>

(46)<smiles>O=C1/C(=C/c2ccc(O)c(O)c2)Oc2c1ccc(OC(O)C1OC(O)C(O)C(O)C1O)c2O</smiles>

(59)

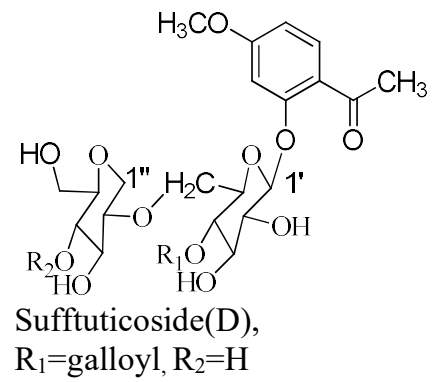

(78) 
RASĀYAN J. Chem.

Vol. 14 | No. 2 |811-828| April - June | 2021

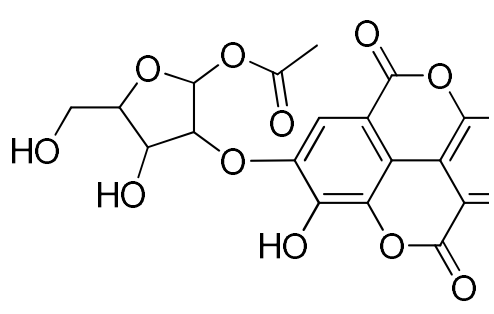

(69)<smiles>C[C@H]1O[C@H](Oc2cc(O)cc3[o+]c(-c4ccc(O)c(O)c4)c(O[C@@H]4O[C@H](CO)[C@@H](O)[C@H](O)[C@H]4O)cc23)[C@H](O)[C@@H](O)[C@H]1O</smiles>

\section{Phenolic Acids}

Fig.-2: Chemical Compositions of the Major Compounds Discovered

The HPLC/QTOF-MS ${ }^{2}$ analysis (in positive ion mode) revealed the presence of six isomers of mono caffeoylquinic acid like-structures (31-36), including chlorogenic acid (3-O-E-caffeoylquinc acid), depending on a molecular ion peak at $\mathrm{m} / \mathrm{z} 355.10299[\mathrm{M}+\mathrm{H}]^{+}$. This group of positional isomers was further proved through the detection of the characteristic fragment positive ions at m/z $193[\mathrm{M}+\mathrm{H}-$ caffeoyl] $]^{+}$or [quinic $\left.+\mathrm{H}\right]^{+}$, and $163[\mathrm{M}+\mathrm{H} \text {-quinoyl }]^{+}$or $[\text {caffeic }+\mathrm{H}]^{+}$, together with a third positive ion at $\mathrm{m} / \mathrm{z} 137 \mathrm{amu}$. According to the matching of such information with the library database, these compounds were tentatively identified as chlorogenic acid, 1-caffeoylquinic acid, 1-O-caffeoylquinic acid, 3-Ocaffeoylquinic acid, 4-O-caffeoylquinic acid and 5-O-caffeoylquinic acid. ${ }^{15}$

\section{Flavonoids}

The flavonoids were tentatively identified by MS/MS pattern (Table 1). The systematic fragmentation of aglycones and their derivatives by LC-MS/MS experiments resulted in key aglycone fragments at $\mathrm{m} / \mathrm{z} 179$ and 151 for quercetin; 257 and 243 for kaempferol; 241 and 175 for luteolin; 225, 201 and 149 for apigenin. ${ }^{16}$ Also, the fragments corresponding to the loss of 162 and 146 amu were indicative of the hexosyl (e.g. glucosyl or galactosyl), and the deoxyhexosyl (e.g. rhamnosyl), the most common sugars found in the case of flavonoids, respectively. Moreover, the presence of the di-O-glycoside flavonoides was concluded according to their typical fragment due to the loss of $308 \mathrm{amu}$, e.g. rutinose or neohesperidose..$^{17}$

\section{Flavones Glycosides}

The molecular ion i.e. $[\mathrm{M}+\mathrm{H}]+$ at $\mathrm{m} / \mathrm{z} 595.16598$ produced fragment ions at $\mathrm{m} / \mathrm{z} 541$ ( loss of $44 \mathrm{amu}, \cdot \mathrm{C}-$ $\mathrm{CH}_{2}$-OH from hexose), 475.0000 (loss of $120 \mathrm{amu}$ from hexose moiety), 355.15847 (loss of $240 \mathrm{amu}$ from di hexoside), 325.15847 (loss of $270 \mathrm{amu}$, aglycone), 271.15847 71( loss of di hexose), 309.15847 (loss of 286, saponarin aglycone ), 449.103652 (loss of 146amu) corresponding to the C-glycoside fragmentation pattern so peak (37) was tentatively identified as apigenin di-C-hexoside. Peaks $(38,39)$ were assigned as di-C, C hexosyl-Apigenin and saponarin, respectively.

Two derivatives of luteolin hexosyl were proposed for compounds $(50,51)$ at $\mathrm{m} / \mathrm{z} 449.10801,[\mathrm{M}+\mathrm{H}]+$. In the MS/MS spectra, the loss of hexose moieties gave a fragment ion at $\mathrm{m} / \mathrm{z} 353.10056,287.10056$, which corresponds to luteolin. These compounds have been characterized as luteolin-C-hexosyl and homoorientin (Isoorientin).

Peak 66 produced a molecular anion at $\mathrm{m} / \mathrm{z} 609.18197$ and diosmetin aglycon, $\mathrm{MS}^{2}$ fragment at $\mathrm{m} / \mathrm{z}$ 301.0719 (M-308, neohesperidose) and 286.048652 which pointed out the presence of diosmetin 7-Oneohesperidoside (neodiosmin). ${ }^{18}$

\section{Flavonols Glycosides}

The components exhibit peaks $(41,42)$ both of them had $[\mathrm{M}+\mathrm{H}]^{+}$at $\mathrm{m} / \mathrm{z} 611.16034$ which resulted in a fragment at m/z 465.104052 (loss of a rhamnose moiety, $147 \mathrm{amu}$ ), 303.0497 (loss of a hexose moiety, 


\section{RASĀYAN J. Chem. \\ Vol. 14 | No. 2 |811-828| April - June | 2021}

162amu and rhamnose ), 274.043952(direct loss of CO), 285.041752 (loss of OH) after loss of two hexoses moieties. In both cases, $\mathrm{MS}^{2}$ spectrum of $\mathrm{m} / \mathrm{z} 303$ yielded quercetin. Peak (41) is tentatively identified as quercetin-3-O- $\beta$-glucopyranosyl-7-O- $\alpha$-rhamnopyranoside while peak (42) was identified as quercetin-3-O-rutinoside (rutin) with MS fragments at 465.0998 and 303.742952obtained due to loss of $308 \mathrm{amu}$ (a rutinosyl unit). ${ }^{19,20}$

Peaks (43-45) had $[\mathrm{M}+\mathrm{H}]^{+}$at $\mathrm{m} / \mathrm{z} 465.10307$ and characteristic fragmentation at $\mathrm{m} / \mathrm{z} 303$ (loss of 162amu), This loss of 162 indicated attachment of the sugar moiety (hexose) to the aglycone part indicating that it was present in glycosidic form and not as an aglycone. The characteristic fragments observed with $\mathrm{m} / \mathrm{z}$ $275[\mathrm{M}+\mathrm{H}-($ glucose $+\mathrm{CO})], \quad 257, \quad\left[\mathrm{M}+\mathrm{H}-\left(\right.\right.$ glucose $\left.\left.+\mathrm{CO}+\mathrm{H}_{2} \mathrm{O}\right)\right], \quad 229 \quad\left[\mathrm{M}+\mathrm{H}-\left(\right.\right.$ glucose $\left.\left.+2 \mathrm{CO}+\mathrm{H}_{2} \mathrm{O}\right)\right]$, $165\left[\mathrm{M}+\mathrm{H}-\left(\right.\right.$ glucose $\left.\left.+3 \mathrm{CO}+3 \mathrm{H}_{2} \mathrm{O}\right)\right]$ and 153 corressponding to $[\mathrm{M}+\mathrm{H}-($ glucose $-\mathrm{H} 2 \mathrm{O}-\mathrm{C} 8 \mathrm{H} 6 \mathrm{O} 3)]+$ were similar to the results reported by ${ }^{12}$ in their study on Phenolic compounds. These compounds were assigned as speriaeoside, quercetin-3-O- $\beta$-glucopyranoside (Isoquercitrin,), and quercetin-3-O- $\beta$-Dgalactoside (hyperoside). ${ }^{21}$

Compound 48 was identified as quercetin 3-O-glucuronide with a pseudomolecular ion at $\mathrm{m} / \mathrm{z} 479.08283$ $[\mathrm{M}+\mathrm{H}]^{+}$and fragment ion 303.0497 after the loss of a glucuronide unit $(176 \mathrm{amu}) .^{20}$

The peaks (52- 54) have identical mass at $\mathrm{m} / \mathrm{z} 433.11541$ with fragments at $\mathrm{m} / \mathrm{z} 287.120202$ (loss 147 amu, rhamnose unit), were identified as kaempferol-3-O-rhamnose, rhamnosyl-kaempferol and kaempferol 7-O-rhamnoside. ${ }^{22}$

A precursor ions of $\mathrm{m} / \mathrm{z} 449.10805,449.1077$ at $\mathrm{R}_{\mathrm{t}}$ of 4.31 and $4.71 \mathrm{~min}$, gave fragment ions at $\mathrm{m} / \mathrm{z}$ $303.047,287.0525,270.10056,245.046852,229.048,181.014252,165,153.115112,121.0277$ corresponding to (Quercetin) fragments due to loss of rhamnosyl moiety (147 amu), compounds ( 63, 64, 67 and 68, , are suggested as quercetin-3- rhamnoside, quercetin-3-O-rhamnose, quercitrin and quercetin3-O- $\alpha$-L-rhamnopyranoside. ${ }^{21,23,24}$

Peaks (55-58) gave the same MS base peak at $\mathrm{m} / \mathrm{z}$ 449.10825, showed fragments at $\mathrm{m} / \mathrm{z} 287.115112$ with the same retention time which corresponds to the characteristic loss of O-hexoside were tentatively assigned as kaempferol 3-O-glucoside, kaempferol 3-glucoside, luteolin-4'-O-glucoside, luteolin-7-Oglucoside and maritimein. ${ }^{25,26}$

\section{Flavanone}

In the positive LC-MS/MS mode, peak (47) exhibited protonated ions at $\mathrm{m} / \mathrm{z} 325.14386$ and produced $\mathrm{MS}^{2}$ ions at $\mathrm{m} / \mathrm{z} 283.137452\left[\mathrm{M}+\mathrm{H}-\left(\mathrm{CH}_{3}-\mathrm{CH}-\mathrm{CH}_{3}\right)\right], 255.138452\left[\mathrm{M}+\mathrm{H}-\left(\mathrm{C}_{5} \mathrm{H}_{10}\right)\right], 238.091052[\mathrm{M}+\mathrm{H}-$ $\left.\left(\mathrm{C}_{5} \mathrm{H}_{10}+\mathrm{OH}\right)\right], 221.079652\left[\mathrm{M}+\mathrm{H}-\left(\mathrm{C}_{5} \mathrm{H}_{10}+2 \mathrm{OH}\right)\right], 165.0164\left[\mathrm{M}+\mathrm{H}-\left(\mathrm{C}_{5} \mathrm{H}_{10}+2 \mathrm{OH}+2 \mathrm{CO}\right)\right]$ and $137.023752\left[\mathrm{M}+\mathrm{H}-\left(\mathrm{C}_{5} \mathrm{H}_{10}+2 \mathrm{OH}+3 \mathrm{CO}\right)\right]$ in the QTOF-MS analysis. This compound was assigned as glabranine based on literature data for hydroxyl flavanon. The exact mass of the peak (47) was $\mathrm{m} / \mathrm{z}$ 325.14386 as stated in (table 1). These measurements were made as a result of the $[\mathrm{M}+\mathrm{H}]^{+}$and the $[\mathrm{M}-$ $\left.\mathrm{C}_{5} \mathrm{H}_{8} \mathrm{O}_{4}+\mathrm{H}\right]^{+}$ions.

\section{Aglycons}

Peaks (60-62) showing a $[\mathrm{M}+\mathrm{H}]^{+}$ion at $\mathrm{m} / \mathrm{z} 287.05539$ and $\mathrm{MS}^{2}$ ions at $\mathrm{m} / \mathrm{z} 231.062292,153.019952$, 153.019952corresponding to the aglycone fragmentation pattern, so were tentatively proposed as fisetin, kaempferol and luteolin. ${ }^{27}$ Peak (29) was identified to be primuliten (7-hydroxy flavones) based on the parent ion at $\mathrm{m} / \mathrm{z} 239.07192$ similar to apigenine aglycon at $\mathrm{m} / \mathrm{z} 271$ by loss of $32 \mathrm{amu}$ ) and the fragment ions obtained at $\mathrm{m} / \mathrm{z} 103.0547,115.0606$ by the expulsion of $\left(\mathrm{C}_{7} \mathrm{H}_{4} \mathrm{O}_{3}\right.$ radical, M-136) from the base molecular ion. ${ }^{28}$

\section{Isoflavone}

Single peak (40) of ipriflavone with protonated molecular ion $[\mathrm{M}+\mathrm{H}]^{+}$at $\mathrm{m} / \mathrm{z} \mathrm{m} / \mathrm{z} 281.11585$. Fragmentation of protonated ipriflavone leads to product ions $\mathrm{m} / \mathrm{z}(1137.021137,165.0686,102.045$, 105.0321) due to cleavage of C-ring, loss of isopropyl group and $\mathrm{H}_{2} \mathrm{O}$, respectively (Table-1). ${ }^{29}$

\section{Anthocyanins Derivatives}

One peak with retention time $0.73 \mathrm{~min}$ and formula $\mathrm{C}_{23} \mathrm{H}_{25} \mathrm{O}_{12}$ exhibited molecular ion at $\mathrm{m} / \mathrm{z} 494.14094$ was assigned to methoxylated anthocyanin glycosides. The product ions at $\mathrm{m} / \mathrm{z} 374.1346$ due to loss of 


\section{RASĀYAN J. Chem. \\ Vol. 14 | No. 2 |811-828| April - June | 2021}

$120 \mathrm{amu}$ from glucose moiety, 331.1346, (M-162 of glucose), 181.1346 and 121.1346 resulted from cleavage of C-ring, were characteristic fragments for malvidin 3-glucoside, Peak (24).

Peak (71) produced $\mathrm{m} / \mathrm{z}=611.3249$ and $\mathrm{MS}^{2}$ fragments 449,287 , resulted in the loss of 3264amu for two glucose units was characterized as cyanidin-3, 5-O-diglucoside. Two isomers $(75,76)$ at $\mathrm{m} / \mathrm{z}=$ 611.28587, 595.28978 and $\mathrm{MS}^{2}$ fragments at 287due to loss of 324amu (sophorosyl unit) and $308 \mathrm{amu}$ (rutinosyl unit) were identified as cyanidin-3-O-sophoroside and cyanidin-3-O-rutinoside. ${ }^{17}$

Peak (80) with $\mathrm{m} / \mathrm{z}=615.3256$ and fragment at 301was identified as 7-O-Methyl-cyanidin-3-O-(2"galloyl). ${ }^{30}$ Peak (83) was identified as proanthocyanidin dimer, $[\mathrm{M}+\mathrm{H}]^{+} 579.33614$ and fragments at 427 , 409,291 , loss of 152amu (By using the retro Diels-Alder reaction, you can create a unique fragmentation pathway.). ${ }^{31}$

\section{Amino Acids}

\section{Aliphatic Amino Acid}

Four isomers of 2-Aminobutyric acid and three derivatives of glycine $\left(\mathrm{C}_{4} \mathrm{H}_{9} \mathrm{NO}_{2}\right)$ at $\mathrm{m} / \mathrm{z} 104.07079$ were observed, peaks $(2-8,22)$, as shown by the appearance of product ions at $\mathrm{m} / \mathrm{z} 58.0658\left(\right.$ loss of $\mathrm{CO}+\mathrm{H}_{2} \mathrm{O}$ ), $57.06333,87.0447$ (loss of $\mathrm{NH}_{3}$ ) and corresponded to N-methyl-DL-alanine, N,N-dimethylglycine, N,Ndimethylglycine hydrochloride, L- $\alpha$-amino-n-butyric acid, L-2-aminobutyric acid, 2-aminoisobutyric acid and-L-2-aminobutyric acid.

The QTOF-MS/MS analysis revealed the presence of seven isomers in the ESI + modes with ions at $\mathrm{m} / \mathrm{z}$ $120.06603,120.06566$, respectively. The appearance of fragment ion at $\mathrm{m} / \mathrm{z} 102.0552,\left(\mathrm{M}-\mathrm{H}_{2} \mathrm{O}\right)$, and product ions at $\mathrm{m} / \mathrm{z} 74.05824,\left[\mathrm{M}-\left(\mathrm{CO}+\mathrm{H}_{2} \mathrm{O}\right)\right]$ corresponded to homoserine isomer in peaks $(9-14,20)$ were assigned as D- $\beta$-homoserine, L- $\beta$-homoserin, L-allo-threonine, D- $\beta$-homoserine [(S)-3-Amino-4hydroxy-butyric acid (-)], L-homoserine and L- $\beta$-homoserine [(R)-3-Amino-4-hydroxy-butyric acid (+)]. The compound $\left(\mathrm{R}_{t} 0.65 \mathrm{~min}\right)$ with the molecular formulaC ${ }_{4} \mathrm{H}_{7} \mathrm{~N}_{1} \mathrm{O}_{4}$ and having the precursor ion at $\mathrm{m} / \mathrm{z}$ 134.04499 in the ESI+ mode, was been tentatively proposed as L-aspartic acid Peak(15) which showed product ions at $\mathrm{m} / \mathrm{z} 115.03751,116.03751,117.052062\left(\operatorname{loss}\right.$ of $\left.\mathrm{H}_{2} \mathrm{O}\right){ }^{32}$

The compounds (25) and (26) possessed a molecular ion at $\mathrm{m} / \mathrm{z} 146.11736$ were characterized as L- $\beta$ homoleucine- $\mathrm{HCl}$ and $\mathrm{L}-\beta$-homoisoleucine hydrochloride due to the characteristic product ions at 86.0961, 69.0711, 55.0559, 86.0969, 83.11028.

\section{Aromatic Amino Acids}

The ions $\mathrm{m} / \mathrm{z} 352.16039[\mathrm{M}+\mathrm{H}]^{+}$and $220.118052\left[\mathrm{M}+\mathrm{H}-\text { ribose } \mathrm{C}_{5} \mathrm{H}_{8} \mathrm{O}_{4}\right]^{+}$are characteristic of transzeatin-riboside, compound (27). A component (16) with molecular ion $[\mathrm{M}+\mathrm{H}]^{+} \mathrm{at} \mathrm{m} / \mathrm{z} 152.05747$ was proposed to be guanine with fragment ions at $\mathrm{m} / \mathrm{z} 135.029852$ (loss of $\mathrm{NH}_{3}$ ), 111.0206, 110 ( loss of $42 \mathrm{amu},-\mathrm{HNCNH}), 68.024552$ [loss of $84 \mathrm{amu}, \mathrm{NH}_{3}{ }^{+}(-\mathrm{HCNCCO})$ ].

Adenosine and 2'-deoxyguanosine monohydrate both had identical formula $\mathrm{C}_{10} \mathrm{H}_{13} \mathrm{~N}_{5} \mathrm{O}_{4}$ with different $\left(\mathrm{R}^{\mathrm{t}}\right.$, $0.86,0.71 \mathrm{~min})$ were suggested for compounds $(18,23), \mathrm{m} / \mathrm{z} 268.10440 / 268.10445,[\mathrm{M}+\mathrm{H}]+$. In the MS/MS spectra, [M-132 (pentose) $+\mathrm{H}]+$ gave a fragment ion at $\mathrm{m} / \mathrm{z} 136.09675$, which corresponds to aglycone of adenosine and $119.035\left[\mathrm{M}+\mathrm{H}-\mathrm{C}_{5} \mathrm{H}_{10} \mathrm{O}_{3}\right]^{+}$. A product ion at 150.09675 formed guanosine radical which characteristic of 2'-deoxyguanosine monohydrate. ${ }^{33}$

The QTOF-MS/MS analysis showed the presence of molecular ion at $\mathrm{m} / \mathrm{z} 310.11343$ in the ESI + mode with product ions at $\mathrm{m} / \mathrm{z} 292.10598,\left(\mathrm{M}-\mathrm{H}_{2} \mathrm{O}\right), 274.10598,\left(\mathrm{M}-2 \mathrm{H}_{2} \mathrm{O}\right), 232.10598,\left(\mathrm{M}-\mathrm{H}_{2} \mathrm{O}+\mathrm{C}_{2} \mathrm{H}_{4} \mathrm{NO}\right.$.) revealed that peak (21) was tentatively proposed as $\mathrm{N}$-acetylneuraminic acid.

There was a dominant neutral loss of $17 \mathrm{amu}$, which could be due to the loss of $\mathrm{NH} 3$ with fragment ion at $\mathrm{m} / \mathrm{z}$ 149.093532and 120.07898, $\left(\mathrm{M}-\mathrm{CO}+\mathrm{H}_{2} \mathrm{O}\right)$ in positive ionization mode. Compound (28) with a precursor ion $[\mathrm{M}+\mathrm{H}]+$ at $\mathrm{m} / \mathrm{z} 166.08616$ and with formula $\mathrm{C}_{9} \mathrm{H}_{11} \mathrm{NO}_{2}$ had been assigned as phenylalanine. ${ }^{32}$

\section{Stilbenes}

Two stilbenes derivatives were tentatively identified in S. grantii. The molecular ion at $\mathrm{m} / \mathrm{z} 391.13934$, fragmentation of the parent ion at $\mathrm{m} / \mathrm{z} 231.1010213,287.1119799,269.1014152,147.0646358$ were produced from cleavage of glucoside and successive losses of $[\mathrm{M}+\mathrm{HCOO}]+$ which corresponded to the molecular formulae of $\mathrm{C}_{20} \mathrm{H}_{22} \mathrm{O}_{8}$. These fragments were fitted to the resveratrol 3-O-glucoside, peak 
RASĀYAN J. Chem.

Vol. 14 | No. 2 |811-828| April - June | 2021

(19).$^{34}$ Compound (17) had a molecular ion at $\mathrm{m} / \mathrm{z}$ 275.09285and MS/MS spectra that showed product ions at $\mathrm{m} / \mathrm{z} 153.017452,121.064552$ were formed from cleavage of bond between methylene and carbonyl group $\mathrm{O}=\mathrm{C}-\mathrm{CH}_{2}, 125.093652,\left(\mathrm{M}-149, \mathrm{C}_{9} \mathrm{H}_{9} \mathrm{O}_{2} \bullet\right.$ ), 229.085352, (M-CO). The compound was characterized as Phloretin.

\section{Hydrolysable Tannins Derivatives}

Two peaks $(71,73)$ showed precursor ions at $\mathrm{m} / \mathrm{z} 547.20978$ and 623.32565 were tentatively identified as dihydroxybenzoic-digallate and galloyl-valoneic acid bilactone. ${ }^{35}$ Four isomers of gallic acid derivatives (74, 79, 81, 82) with molecular formula $\mathrm{C}_{21} \mathrm{H}_{14} \mathrm{O}_{13}, \quad \mathrm{C}_{20} \mathrm{H}_{20} \mathrm{O}_{14}, \mathrm{C}_{27} \mathrm{H}_{22} \mathrm{O}_{17}$ and $\mathrm{C}_{27} \mathrm{H}_{24} \mathrm{O}_{18}$ exhibited molecular ions at $\mathrm{m} / \mathrm{z} 475.24853,485.25135,619.27619$ and 637.25234 with fragment ions at 323,425 , $303,, 153333,171,485,467$ were assigned as Trigallic acid, Trigalloyllevoglucosan, di and tri galloyl hexoside. ${ }^{16,36}$ Peak (84) was detected as galloyl-HHDP-glucose (corilagin isomer with molecular ion $\mathrm{m} / \mathrm{z}$ 635.28597 produced $\mathrm{MS}^{2}$ fragments at 483 by loss of galloyl unit and 303(loss of galloylglucose) as the main fragment. ${ }^{17}$

Table-1: Tentative Identification of the Phytoconstituents from the Methanol Extract of S. grantii aerial parts by (LC-QTOF-MS/MS) in Possitive Mode

\begin{tabular}{|c|c|c|c|c|c|c|}
\hline Peak & Formulae & $\begin{array}{c}\mathrm{Rt} \\
(\mathrm{min})\end{array}$ & $\begin{array}{l}\text { LC-MS } \\
{[\mathrm{M}+\mathrm{H}]^{+}}\end{array}$ & $\begin{array}{l}\text { QTOF- } \\
\text { MS-MS }\end{array}$ & Tentative Assignment & Intensity \\
\hline 1 & $\mathrm{C}_{15} \mathrm{H}_{16} \mathrm{O}_{5}$ & 0.53 & 277.10608 & $\begin{array}{l}208,193, \\
207,163,\end{array}$ & Capensine & 5841 \\
\hline 2 & $\mathrm{C}_{4} \mathrm{H}_{9} \mathrm{NO}_{2}$ & 0.57 & 104.07079 & 58,57 & N-Methyl-DL-Alanine & 3498 \\
\hline 3 & $\mathrm{C}_{4} \mathrm{H}_{9} \mathrm{~N}_{1} \mathrm{O}_{2}$ & 0.57 & 104.07079 & 58 & N,N-Dimethylglycine & 3498 \\
\hline 4 & $\mathrm{C}_{4} \mathrm{H}_{9} \mathrm{~N}_{1} \mathrm{O}_{2}$ & 0.57 & 104.07079 & 58,57 & $\begin{array}{c}\text { N,N-Dimethylglycine } \\
\text { hydrochloride }\end{array}$ & 3498 \\
\hline 5 & $\mathrm{C}_{4} \mathrm{H}_{9} \mathrm{~N}_{1} \mathrm{O}_{2}$ & 0.57 & 104.07079 & 58,87 & $\begin{array}{c}\text { L- } \alpha \text {-Amino-n-butyric } \\
\text { acid }\end{array}$ & 3498 \\
\hline 6 & $\mathrm{C}_{4} \mathrm{H}_{9} \mathrm{NO}_{2}$ & 0.57 & 104.07079 & 58,57 & L-2-Aminobutyric acid & 2755 \\
\hline 7 & $\mathrm{C}_{4} \mathrm{H}_{9} \mathrm{NO}_{2}$ & 0.57 & 104.07079 & 58,57 & 2-Aminoisobutyric acid & 3498 \\
\hline 8 & $\mathrm{C}_{4} \mathrm{H}_{9} \mathrm{NO}_{2}$ & 0.57 & 104.07079 & 58,57 & $\begin{array}{c}\text { D-L-2-Aminobutyric } \\
\text { acid }\end{array}$ & 3498 \\
\hline 9 & $\mathrm{C}_{4} \mathrm{H}_{9} \mathrm{NO}_{3}$ & 0.61 & 120.06603 & 102,60 & D- $\beta$-Homoserine & 2382 \\
\hline 10 & $\mathrm{C}_{4} \mathrm{H}_{9} \mathrm{NO}_{3}$ & 0.61 & 120.06603 & $102,60,84$ & L- $\beta$-Homoserin & 2382 \\
\hline 11 & $\mathrm{C}_{4} \mathrm{H}_{9} \mathrm{NO}_{3}$ & 0.61 & 120.06603 & $102,74,84,56$ & L-allo-threonine & 2382 \\
\hline 12 & $\mathrm{C}_{4} \mathrm{H}_{9} \mathrm{NO}_{3}$ & 0.62 & 120.06603 & $102,85,76,74$ & $\begin{array}{l}\text { D- } \beta \text {-Homoserine }[(\mathrm{S})- \\
\text { 3-Amino-4-hydroxy- } \\
\text { butyric acid }(-)]\end{array}$ & 2382 \\
\hline 13 & $\mathrm{C}_{4} \mathrm{H}_{9} \mathrm{NO}_{3}$ & 0.63 & 120.06566 & $\begin{array}{c}102,74,92, \\
73,56\end{array}$ & L-Homoserine & 2755 \\
\hline 14 & $\mathrm{C}_{4} \mathrm{H}_{9} \mathrm{NO}_{3}$ & 0.61 & 120.06566 & 102,85 & $\begin{array}{c}\text { L- } \beta \text {-Homoserine }[(\mathrm{R})- \\
\text { 3-Amino-4-hydroxy- } \\
\text { butyric acid }(+)\end{array}$ & 2755 \\
\hline 15 & $\mathrm{C}_{4} \mathrm{H}_{7} \mathrm{~N}_{1} \mathrm{O}_{4}$ & 0.65 & 134.04499 & $\begin{array}{c}115,117 \\
116 \\
\end{array}$ & L-Aspartic acid & 1917 \\
\hline 16 & $\mathrm{C}_{5} \mathrm{H}_{5} \mathrm{~N}_{5} \mathrm{O}$ & 0.65 & 152.05747 & $\begin{array}{c}135,110 \\
111,68\end{array}$ & Guanine & 2534 \\
\hline 17 & $\mathrm{C}_{15} \mathrm{H}_{14} \mathrm{O}_{5}$ & 0.66 & 275.09285 & $\begin{array}{c}169,153, \\
121,125, \\
235,231 \\
229\end{array}$ & Phloretin & 1255 \\
\hline 18 & $\mathrm{C}_{10} \mathrm{H}_{13} \mathrm{~N}_{5} \mathrm{O}_{4}$ & 0.68 & 268.10440 & $\begin{array}{l}136,135 \\
119,118 \\
116,107\end{array}$ & Adenosin & 3699 \\
\hline
\end{tabular}


RASĀYAN J. Chem.

Vol. 14 | No. 2 |811-828| April - June | 2021

\begin{tabular}{|c|c|c|c|c|c|c|}
\hline 19 & $\mathrm{C}_{20} \mathrm{H}_{22} \mathrm{O}_{8}$ & 0.69 & 391.13934 & $\begin{array}{l}231,287 \\
\text { 269ni, } \\
265 \mathrm{ni}, 147, \\
\end{array}$ & $\begin{array}{l}\text { Resveratrol 3-O- } \\
\text { glucoside }\end{array}$ & 1561 \\
\hline 20 & $\mathrm{C}_{4} \mathrm{H}_{9} \mathrm{NO}_{3}$ & 0.69 & 120.06603 & $74,102,84$ & L-Threoninel & 2368 \\
\hline 21 & $\mathrm{C}_{11} \mathrm{H}_{19} \mathrm{NO}_{9}$ & 0.7 & 310.11343 & $\begin{array}{c}292,274 \\
232,169 \\
103 \\
\end{array}$ & $\begin{array}{l}\text { N-Acetylneuraminic } \\
\text { acid }\end{array}$ & 1955 \\
\hline 22 & $\mathrm{C}_{4} \mathrm{H}_{9} \mathrm{NO}_{2}$ & 0.71 & 104.07061 & 87,69 & $\gamma$-Amino-n-butyric acid & 3565 \\
\hline 23 & $\mathrm{C}_{10} \mathrm{H}_{13} \mathrm{~N}_{5} \mathrm{O}_{4}$ & 0.71 & 268.10445 & 150 & $\begin{array}{l}\text { 2'-Deoxyguanosine } \\
\text { monohydrate }\end{array}$ & 3699 \\
\hline 24 & $\mathrm{C}_{23} \mathrm{H}_{25} \mathrm{O}_{12}$ & 0.73 & 494.14094 & $\begin{array}{l}374,331 \\
181,121\end{array}$ & Malvidin 3-glucoside & 883 \\
\hline 25 & $\mathrm{C}_{7} \mathrm{H}_{15} \mathrm{NO}_{2}$ & 0.76 & 146.11736 & $86,69,55$ & L- $\beta$-Homoleucine-HCl & 1613 \\
\hline 26 & $\mathrm{C}_{7} \mathrm{H}_{15} \mathrm{NO}_{2}$ & 0.76 & 146.11736 & $\begin{array}{c}86,68,55 \\
83\end{array}$ & $\begin{array}{l}\text { L- } \beta \text {-Homoisoleucine } \\
\text { hydrochloride }\end{array}$ & 1613 \\
\hline 27 & $\mathrm{C}_{15} \mathrm{H}_{21} \mathrm{~N}_{5} \mathrm{O}_{5}$ & 0.79 & 352.16039 & $\begin{array}{c}220,136, \\
333251,202\end{array}$ & Trans-Zeatin-riboside & 1271 \\
\hline 28 & $\mathrm{C}_{9} \mathrm{H}_{11} \mathrm{NO}_{2}$ & 0.8 & 166.08616 & $\begin{array}{l}149,120 \\
118,105\end{array}$ & L-(-)-Phenylalanine & 130007 \\
\hline 29 & $\mathrm{C}_{15} \mathrm{H}_{10} \mathrm{O}_{3}$ & 0.99 & 239.07192 & 103,115 & Primuliten & 1421 \\
\hline 30 & $\mathrm{C}_{19} \mathrm{H}_{12} \mathrm{O}_{7}$ & 1.21 & 353.06511 & $\begin{array}{c}165,310 \\
254,208 \\
147\end{array}$ & Daphnoretin & 1293 \\
\hline 31 & $\mathrm{C}_{16} \mathrm{H}_{18} \mathrm{O}_{9}$ & 1.23 & 355.10299 & $\begin{array}{c}193,163 \\
137\end{array}$ & Chlorogenic acid & 52946 \\
\hline 32 & $\mathrm{C}_{16} \mathrm{H}_{18} \mathrm{O}_{9}$ & 1.23 & 355.10299 & 193 & 1-Caffeoylquinic acids & 52946 \\
\hline 33 & $\mathrm{C}_{16} \mathrm{H}_{18} \mathrm{O}_{9}$ & 1.23 & 355.10299 & 193 & $\begin{array}{c}\text { 1-O-Caffeoylquinic } \\
\text { acids } \\
\end{array}$ & 52946 \\
\hline 34 & $\mathrm{C}_{16} \mathrm{H}_{18} \mathrm{O}_{9}$ & 1.23 & 355.10299 & 193 & 3-Caffeoylquinic acids & 52946 \\
\hline 35 & $\mathrm{C}_{16} \mathrm{H}_{18} \mathrm{O}_{9}$ & 1.23 & 355.10299 & 193 & 4-Caffeoylquinic acids & 52946 \\
\hline 36 & $\mathrm{C}_{16} \mathrm{H}_{18} \mathrm{O}_{9}$ & 1.23 & 355.10299 & $\begin{array}{l}193,162 \\
192,116\end{array}$ & 5-Caffeoylquinic acids & 52946 \\
\hline 37 & $\mathrm{C}_{27} \mathrm{H}_{30} \mathrm{O}_{15}$ & 1.93 & 595.16598 & $\begin{array}{l}541,475 \\
355,325\end{array}$ & Apigenindi-C-hexoside & 839 \\
\hline 38 & $\mathrm{C}_{27} \mathrm{H}_{30} \mathrm{O}_{15}$ & 1.93 & 595.16598 & $\begin{array}{l}457,439 \\
409,307 \\
295 \\
\end{array}$ & $\begin{array}{l}\text { Di-C,C hexosyl- } \\
\text { Apigenin }\end{array}$ & 835 \\
\hline 39 & $\mathrm{C}_{27} \mathrm{H}_{30} \mathrm{O}_{15}$ & 1.94 & 595.16598 & $\begin{array}{c}449,336 \\
309,282 \\
271 \\
\end{array}$ & Saponarin & 839 \\
\hline 40 & $\mathrm{C}_{18} \mathrm{H}_{16} \mathrm{O}_{3}$ & 3.16 & 281.11585 & $\begin{array}{l}165,137, \\
105,102\end{array}$ & Ipriflavone & 1649 \\
\hline 41 & $\mathrm{C}_{27} \mathrm{H}_{30} \mathrm{O}_{16}$ & 3.49 & 611.16034 & $\begin{array}{l}303,465 \\
247,153\end{array}$ & $\begin{array}{l}\text { Quercetin-3-O- } \beta- \\
\text { glucopyranosyl-7-O- } \alpha- \\
\text { rhamnopyranoside }\end{array}$ & 9795 \\
\hline 42 & $\mathrm{C}_{27} \mathrm{H}_{30} \mathrm{O}_{16}$ & 3.49 & 611.16034 & $\begin{array}{l}302,465 \\
322,285 \\
181,153 \\
272 \\
\end{array}$ & Rutin & 9795 \\
\hline 43 & $\mathrm{C}_{21} \mathrm{H}_{20} \mathrm{O}_{12}$ & 3.63 & 465.10307 & $\begin{array}{l}303,302, \\
257,201 \\
165,153 \\
\end{array}$ & Speriaeoside & 20911 \\
\hline
\end{tabular}


RASĀYAN J. Chem.

Vol. 14 | No. 2 |811-828| April - June | 2021

\begin{tabular}{|c|c|c|c|c|c|c|}
\hline 44 & $\mathrm{C}_{21} \mathrm{H}_{20} \mathrm{O}_{12}$ & 3.63 & 465.10307 & $\begin{array}{c}303,285, \\
272,245, \\
229,165, \\
153,109, \\
273,229\end{array}$ & $\begin{array}{l}\text { Quercetin-3-O- } \beta \text { - } \\
\text { glucopyranoside }\end{array}$ & 20911 \\
\hline 45 & $\mathrm{C}_{21} \mathrm{H}_{20} \mathrm{O}_{12}$ & 3.63 & 465.10307 & $\begin{array}{l}303,302, \\
297,257, \\
245,229, \\
201,165, \\
153\end{array}$ & $\begin{array}{l}\text { Quercetin-3-O- } \beta \text {-D- } \\
\text { galactoside } \\
\text { (Hyperoside) }\end{array}$ & 20911 \\
\hline 46 & $\mathrm{C}_{17} \mathrm{H}_{22} \mathrm{~N}_{2} \mathrm{O}_{10} \mathrm{~S}_{2}$ & 3.63 & 479.08085 & $\begin{array}{l}465,301 \\
293,261\end{array}$ & $\begin{array}{l}\text { 4-Methoxy-3- } \\
\text { indolylmethyl } \\
\text { glucosinolate }\end{array}$ & 599 \\
\hline 47 & $\mathrm{C}_{20} \mathrm{H}_{20} \mathrm{O}_{4}$ & 3.64 & 325.14386 & $\begin{array}{l}221,165, \\
135,283, \\
269,240, \\
222,189\end{array}$ & Glabranine & 1199 \\
\hline 48 & $\mathrm{C}_{21} \mathrm{H}_{18} \mathrm{O}_{13}$ & 3.71 & 479.08283 & $\begin{array}{c}303,302, \\
299,257, \\
229,201, \\
165,153, \\
109,\end{array}$ & $\begin{array}{l}\text { Quercetin-3- } \\
\text { Glucuronide }\end{array}$ & 631 \\
\hline 49 & $\mathrm{C}_{19} \mathrm{H}_{22} \mathrm{O}_{6}$ & 3.76 & 347.14937 & $\begin{array}{c}239, \\
227,213,143 \\
\end{array}$ & Gibberelin A3 & 624 \\
\hline 50 & $\mathrm{C}_{21} \mathrm{H}_{20} \mathrm{O}_{11}$ & 3.84 & 449.10801 & 353,287 & Luteolin-C-hexosyl & 136475 \\
\hline 51 & $\mathrm{C}_{21} \mathrm{H}_{20} \mathrm{O}_{11}$ & 3.84 & 449.10801 & $\begin{array}{c}353,412, \\
368330,328 \\
\end{array}$ & $\begin{array}{c}\text { Homoorientin } \\
\text { (Isoorientin) }\end{array}$ & 136475 \\
\hline 52 & $\mathrm{C}_{21} \mathrm{H}_{20} \mathrm{O}_{10}$ & 3.92 & 433.11541 & 287,229 & $\begin{array}{c}\text { Kaempferol-3-O- } \\
\text { rhamnose }\end{array}$ & 708 \\
\hline 53 & $\mathrm{C}_{21} \mathrm{H}_{20} \mathrm{O}_{10}$ & 3.92 & 433.11541 & 287 & Rhamnosyl-kaempferol & 708 \\
\hline 54 & $\mathrm{C}_{21} \mathrm{H}_{20} \mathrm{O}_{10}$ & 3.92 & 433.11541 & 287 & $\begin{array}{l}\text { Kaempferol 7-O- } \\
\text { rhamnoside }\end{array}$ & 137258 \\
\hline 55 & $\mathrm{C}_{21} \mathrm{H}_{20} \mathrm{O}_{11}$ & 4.02 & 449.10825 & $\begin{array}{c}287,286, \\
258,153 \\
165 \\
\end{array}$ & $\begin{array}{l}\text { kaempferol-3-O- } \\
\text { glucoside }\end{array}$ & 135868 \\
\hline 56 & $\mathrm{C}_{21} \mathrm{H}_{20} \mathrm{O}_{11}$ & 4.02 & 449.10825 & $\begin{array}{l}287,286, \\
284,258, \\
185,165 \\
229,257\end{array}$ & $\begin{array}{l}\text { kaempferol-3- } \\
\text { glucoside }\end{array}$ & 135868 \\
\hline 57 & $\mathrm{C}_{21} \mathrm{H}_{20} \mathrm{O}_{11}$ & 4.02 & 449.10825 & $\begin{array}{c}287,284 \\
201,177 \\
\end{array}$ & luteolin-4'-O-glucoside & 135868 \\
\hline 58 & $\mathrm{C}_{21} \mathrm{H}_{20} \mathrm{O}_{11}$ & 4.02 & 449.10825 & $\begin{array}{c}287,284258, \\
201\end{array}$ & luteolin-7-O-glucoside & 135868 \\
\hline 59 & $\mathrm{C}_{21} \mathrm{H}_{20} \mathrm{O}_{11}$ & 4.02 & 449.10825 & $\begin{array}{c}287,284 \\
241,185 \\
152,135 \\
123,107 \\
105\end{array}$ & Maritimein & 135868 \\
\hline 60 & $\mathrm{C}_{15} \mathrm{H}_{10} \mathrm{O}_{6}$ & 4.26 & 287.05534 & $\begin{array}{c}231,165 \\
258,197 \\
\end{array}$ & Fisetin & 36814 \\
\hline 61 & $\mathrm{C}_{15} \mathrm{H}_{10} \mathrm{O}_{6}$ & 4.26 & 287.05539 & $\begin{array}{l}231,229 \\
153,165 \\
\end{array}$ & Kaempferol & 36727 \\
\hline 62 & $\mathrm{C}_{15} \mathrm{H}_{10} \mathrm{O}_{6}$ & 4.26 & 287.05539 & 153 & Luteolin & 36727 \\
\hline 63 & $\mathrm{C}_{21} \mathrm{H}_{20} \mathrm{O}_{11}$ & 4.31 & 449.10805 & $\begin{array}{l}303,287, \\
270,\end{array}$ & $\begin{array}{l}\text { Quercetin-3- } \\
\text { rhamnoside }\end{array}$ & 136374 \\
\hline
\end{tabular}


RASĀYAN J. Chem.

Vol. 14 | No. 2 |811-828| April - June | 2021

\begin{tabular}{|c|c|c|c|c|c|c|}
\hline & & & & $\begin{array}{c}165,229 \\
147,153 \\
121 \\
\end{array}$ & & \\
\hline 64 & $\mathrm{C}_{21} \mathrm{H}_{20} \mathrm{O}_{11}$ & 4.31 & 449.10805 & $\begin{array}{c}303,302, \\
153 \\
\end{array}$ & $\begin{array}{c}\text { Quercetin-3-O- } \\
\text { rhamnose }\end{array}$ & 136374 \\
\hline 65 & $\mathrm{C}_{24} \mathrm{H}_{22} \mathrm{~N}_{4} \mathrm{O}$ & 4.61 & 383.18691 & $\begin{array}{l}261,351 \\
281,145 \\
132\end{array}$ & $\begin{array}{c}1-(2,3- \\
\text { dibenzimidazolyl-2- } \\
\text { propyl)-2- } \\
\text { methoxybenzene }\end{array}$ & 1142 \\
\hline 66 & $\mathrm{C}_{28} \mathrm{H}_{32} \mathrm{O}_{1} 5$ & 4.63 & 609.18197 & 301,286 & Neodiosmin & 720 \\
\hline 67 & $\mathrm{C}_{21} \mathrm{H}_{20} \mathrm{O}_{11}$ & 4.71 & 449.1077 & $\begin{array}{c}302, \\
287,285, \\
245,201, \\
165,153, \\
147\end{array}$ & Quercitrin & 137258 \\
\hline 68 & $\mathrm{C}_{21} \mathrm{H}_{20} \mathrm{O}_{11}$ & 4.71 & 449.1077 & $\begin{array}{c}303,287, \\
286,270, \\
245,229, \\
181,165, \\
153,\end{array}$ & $\begin{array}{l}\text { Quercetin-3-O- } \alpha-\mathrm{L}- \\
\text { rhamnopyranoside }\end{array}$ & 137258 \\
\hline 69 & $\mathrm{C}_{21} \mathrm{H}_{16} \mathrm{O}_{13}$ & 5.13 & 477.10238 & 303 & $\begin{array}{l}\text { Ellagic acid acetyl } \\
\text { pentoside }\end{array}$ & $\begin{array}{c}37564 \\
\text { Dinche } \\
\text { va I }\end{array}$ \\
\hline 70 & $\mathrm{C}_{24} \mathrm{H}_{18} \mathrm{O}_{15}$ & 10.91 & 547.20978 & $\begin{array}{c}471,395 \\
171\end{array}$ & $\begin{array}{l}\text { Dihydroxybenzoic } \\
\text { acetate-digallate }\end{array}$ & 6356 \\
\hline 71 & $\mathrm{C}_{27} \mathrm{H}_{31} \mathrm{O}_{16}$ & 11.6 & 611.3249 & 449,287 & $\begin{array}{l}\text { cyanidin-3, 5-O- } \\
\text { diglucoside }\end{array}$ & $\begin{array}{c}20351 \\
2013\end{array}$ \\
\hline 72 & $\mathrm{C}_{32} \mathrm{H}_{46} \mathrm{O}_{9}$ & 13.9 & 575.32723 & 472 & Ganoderic acid K & 4539 \\
\hline 73 & $\mathrm{C}_{22} \mathrm{H}_{22} \mathrm{O}_{21}$ & 14.17 & 623.32565 & $\begin{array}{c}471,395, \\
171,141 \\
\end{array}$ & $\begin{array}{c}\text { Galloyl-valoneic acid } \\
\text { bilactone }\end{array}$ & 263226 \\
\hline 74 & $\mathrm{C}_{20} \mathrm{H}_{20} \mathrm{O}_{14}$ & 14.17 & 485.25135 & $\begin{array}{c}425,333 \\
171\end{array}$ & Digalloyl-hexoside & 20719 \\
\hline 75 & $\mathrm{C}_{27} \mathrm{H}_{31} \mathrm{O}_{16}$ & 15.5 & 611.28587 & 287 & $\begin{array}{l}\text { cyanidin-3-O- } \\
\text { sophoroside }\end{array}$ & 1972 \\
\hline 76 & $\mathrm{C}_{27} \mathrm{H}_{29} \mathrm{O}_{15}$ & 15.64 & 595.28978 & 449,287 & $\begin{array}{l}\text { cyanidin-3-O- } \\
\text { rutinoside }\end{array}$ & 12534 \\
\hline 77 & $\mathrm{C}_{27} \mathrm{H}_{32} \mathrm{O}_{16}$ & 15.65 & 613.17775 & $\begin{array}{c}345,315 \\
303\end{array}$ & Suffruticoside B & 1385 \\
\hline 78 & $\mathrm{C}_{27} \mathrm{H}_{32} \mathrm{O}_{16}$ & 15.65 & 613.17775 & $\begin{array}{l}345,315 \\
303\end{array}$ & Suffruticoside D & 1385 \\
\hline 79 & $\mathrm{C}_{21} \mathrm{H}_{14} \mathrm{O}_{13}$ & 15.66 & 475.24853 & 323,171 & Trigallic acid & 34122 \\
\hline 80 & $\mathrm{C}_{29} \mathrm{H}_{26} \mathrm{O}_{15}$ & 15.67 & 615.3256 & 301 & $\begin{array}{l}\text { 7-O-Methyl-cyanidin- } \\
\text { 3-O-(2"-galloyl)- } \\
\text { galactosid }\end{array}$ & 14055 \\
\hline 81 & $\mathrm{C}_{27} \mathrm{H}_{22} \mathrm{O}_{17}$ & 15.72 & 619.27619 & 303,153 & Trigalloyllevoglucosan & 11231 \\
\hline 82 & $\mathrm{C}_{27} \mathrm{H}_{24} \mathrm{O}_{18}$ & 15.76 & 637.25234 & $\begin{array}{c}485,467 \\
171\end{array}$ & Tri-galloyl-hexosid & 8080 \\
\hline 83 & $\mathrm{C}_{30} \mathrm{H}_{24} \mathrm{O}_{12}$ & 15.88 & 579.33614 & $\begin{array}{c}427,409, \\
291\end{array}$ & $\begin{array}{c}\text { proanthocyanidin } \\
\text { dimer }\end{array}$ & 59025 \\
\hline 84 & $\mathrm{C}_{27} \mathrm{H}_{22} \mathrm{O}_{18}$ & 19.05 & 635.28597 & 483,303 & $\begin{array}{l}\text { galloyl-HHDP-glucose } \\
\text { (corilagin } \\
\text { isomer }\end{array}$ & $\begin{array}{l}1311 \\
2013\end{array}$ \\
\hline
\end{tabular}


RASĀYAN J. Chem.

Vol. 14 | No. 2 |811-828| April - June | 2021

\section{Other Organic Compounds}

Two isomers with high retention time 15.65 min of peaks $(77,78)$ had the molecular formula $\left(\mathrm{C}_{27} \mathrm{H}_{32} \mathrm{O}_{16}\right)$, exhibited an ion $[\mathrm{M}+\mathrm{H}]+$ at $\mathrm{m} / \mathrm{z} 613.17775$ which yielded major fragment ions at $\mathrm{m} / \mathrm{z} 345.183592$ resulted from loss of 152 ( gallate moiety), 132 (pentose unit ), $\left(\mathrm{M}-\mathrm{C}_{2} \mathrm{H}_{3} \mathrm{O}\right)$ and $\mathrm{OH}$ radicalfrom glucose unit respectively. Fragment ions at $m / z 315.183592$ corresponding to (loss of $298, \mathrm{C}_{13} \mathrm{H}_{15} \mathrm{O}_{8}$ ) and 303.183592 (loss of $\mathrm{C}_{13} \mathrm{H}_{15} \mathrm{O}_{8}+\mathrm{CH}_{3}$ ) indicating the presence of glucose, pentose and galloyl units in their structures. These compounds were assigned to suffruticoside B and D. ${ }^{37}$

\section{Pharmacological Evaluation}

\section{Antioxidant Capacity}

Several studies associate antioxidant activities with terpenes compounds that are present in plant extracts. Results in Fig.-3A showed that DPPH radical scavenging activity of AME increased gradually by increasing the concentration of the extract. It reached to be $82.40 \pm 0.24 \%$ at the concentration of $500 \mu \mathrm{g} / \mathrm{ml}$. This activity is very close to that of the synthetic antioxidant BHA at the same concentration $(92.85 \pm 0.35 \%)$. RPC also increased gradually by increasing the concentration of the extract. Figure-3B indicates that all tested concentrations exhibited a potent reducing power capacity even more than BHA at the same concentration $(500 \mu \mathrm{g} / \mathrm{ml})$ they recorded $1.41 \pm 0.02$ and $0.83 \pm 0.02$ (absorbance at $700 \mathrm{~nm}$ ), respectively. Results in figure $3 \mathrm{C}$ indicated that the $\mathrm{AME}$ possesses the good iron metal chelating ability, it found to be $75.69 \pm 0.30 \%$ at the concentration $3 \mathrm{mg} / \mathrm{ml}$. On the other hand, ABTS radical scavenging activity results are given in Fig.-3D, which is demonstrated the same trend, i.e. increased gradually by increasing the concentration of the extract at concentrations beginning from 50 to $500 \mu \mathrm{g} / \mathrm{ml}$, where it is ranged from $38.35 \pm 0.22$ to $90.27 \pm 0.16 \%$ Furthermore, the results of FRAP are expressed in $\mu$ mol Trolox / g dry matter (Fig.-3E). The investigated extract recorded very promising FRAP. The values obtained by FRAP assay were $2787 \pm 27.10 \mu \mathrm{mol}$ Trolox $/ 100 \mathrm{~g}$ D.W.at the concentration of $500 \mu \mathrm{g} / \mathrm{ml}$. Similar results were found by Elkarim et al., $2020^{10}$, they stated that the NMR analyses of the aerial parts of S. Grantii possess an abundance content of flavonoids and tannins which are mainly attributed to the ability of the isolated compounds to inhibit the free radical formation, therefore the high capacity of the compounds as antioxidant agents which clearly explains and confirms the high radical scavenging activity of the methanol extract.

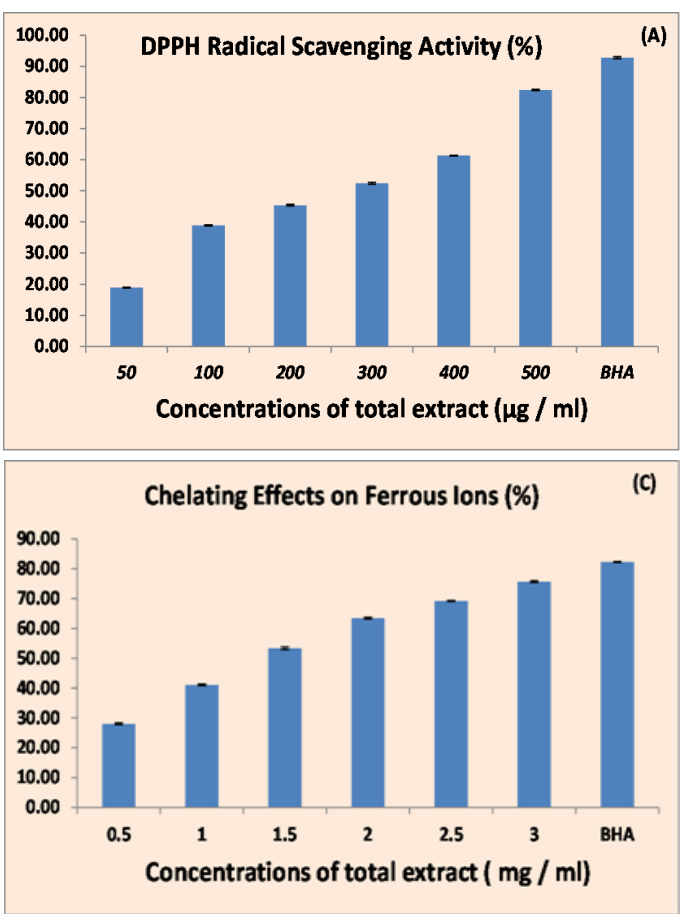

Synadenium grantii Hook f.

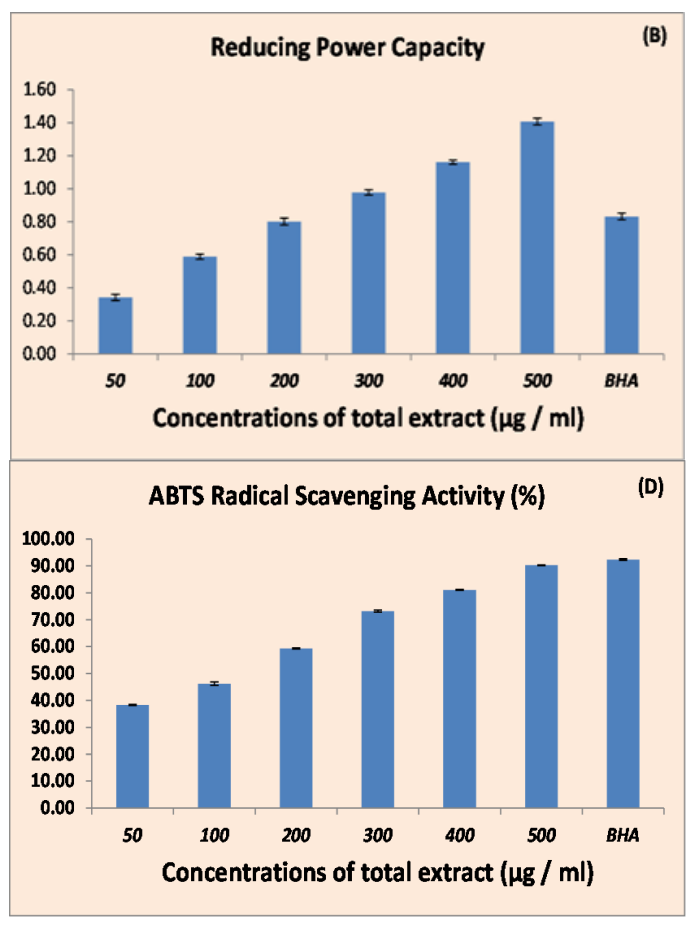

824 
RASĀYAN J. Chem.

Vol. 14 | No. 2 |811-828| April - June | 2021

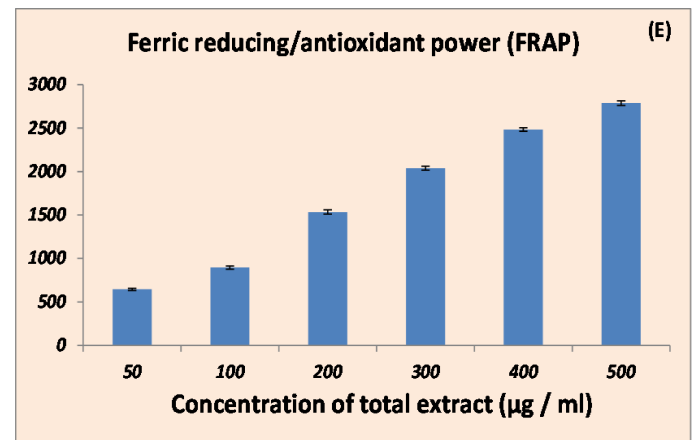

Fig.-3: Antioxidant Activity of (AM) Extract using Different Antioxidant Assays: (A) Scavenging Ability on DPPH radical, (B) Reducing Power, (C) Metal Chelating Activity, (D) Scavenging Ability on ABTS Radicals, (E)

Antioxidant Capacity FRAP Assay. Data are means \pm Standard Deviation of Triplicate Experiments

Also, Our results are very close to the newly published results which suggested that $S$. grantii has different types of phenolic compounds and therefore possesses the ability to scavenge free radicals. ${ }^{38}$ Data found by Gülçin $2010^{39}$, explains that phenolic compounds, such as resveratrol, affect a wide range of intracellular mediators as well as inhibiting lipid peroxidation more strongly than the antioxidants BHA, BHT, $\alpha$-tocopherol, and trolox. ${ }^{39}$

On the other hand LC-MS/MS analysis clearly showed the presence of many phenolic compounds in (MSP) prepared from $S$. grantii aerial parts which possessed the ability to inhibit the formation of free radicals. These findings show and explain the importance of evaluating antioxidant activity, since it depends on the structural characteristics of organic compounds, in most cases due to the presence of terpenes and, mainly, phenolic groups ${ }^{40}$ Flavonoids and tannins contain many functional hydroxyl groups which are considered the main factor of antioxidant effects by scavenging free radicals and also maybe through chelating metal ions. ${ }^{41}$

\section{MIC Determination and Antibiofilm Activity}

The minimum inhibitory concentration of (AM) extract was against bacteria and yeast was illustrated in (Table-2). Bacillus subtilis was the most sensitive bacterial strain to it where the MIC value is $2 \mathrm{mg} / \mathrm{ml}$. of (AME) exhibited excellent biofilm preventing agent against S.aureusat concentrations below the lethal dose without affecting bacterial growth where, concentrations $0.5,0.25$ and $0.125, \mathrm{mg} / \mathrm{ml}$ of (AME) reduce $S$. aureus biofilm formation with proportions $97.1,92.8$ and $78.1 \%$ respectively in dose-dependent manner (Fig.-4). while on the other hand, gram negative $P$. aeruginosa biofilm formation didn't affect by of AME (Fig.-5).

Further to evaluate the effect of (AM) extract on the surface topology of $S$. aureus biofilm matrix, inverted light microscopic analysis was carried out and the results showed the presence of thick biofilm matrix with micro colony formation in control, while of (AME) treated groups exhibited no colonization and $S$. aureuscells appear as scattered separated cells in dose-dependent manner (Fig.-6).

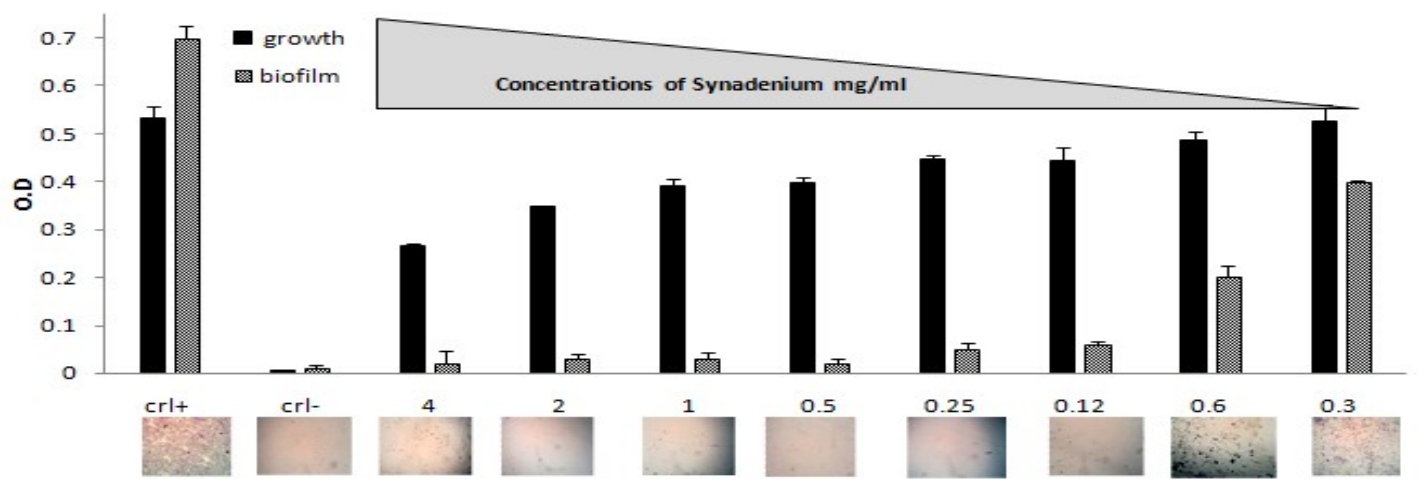

Fig.-4: Antibiofilm of (AM) Extract against S.aureus exhibit inhibition of Biofilm formation up to $98 \%$ at concentrations $2.0-0.125 \mathrm{mg} / \mathrm{ml}$ 
RASĀYAN J. Chem.

Vol. 14 | No. 2 |811-828| April - June | 2021

Table-2: Minimum Inhibitory Concentration (MIC) of of (AM) Extract (mg/ml*)

\begin{tabular}{l|l|l|l|l|l|l}
\hline $\mathrm{IC} \mathrm{mg} / \mathrm{ml}$ & $\begin{array}{l}\text { of } \\
\text { extract }\end{array}$ & S. $a^{1}$ & B.s & E. $c^{3}$ & P. $a^{4}$ & C. $a l^{5}$ \\
\hline 6.0 & MIC & 5.0 & 2.0 & 4.0 & 5.0 & 4.0 \\
\hline
\end{tabular}

*mg/ml; of (AM) extract milligram / milliliter,IC; initial concentration1;S. aureus2; Bacillus subtilis3; E. coli4; P. aeruginosa, and5; C. albicans

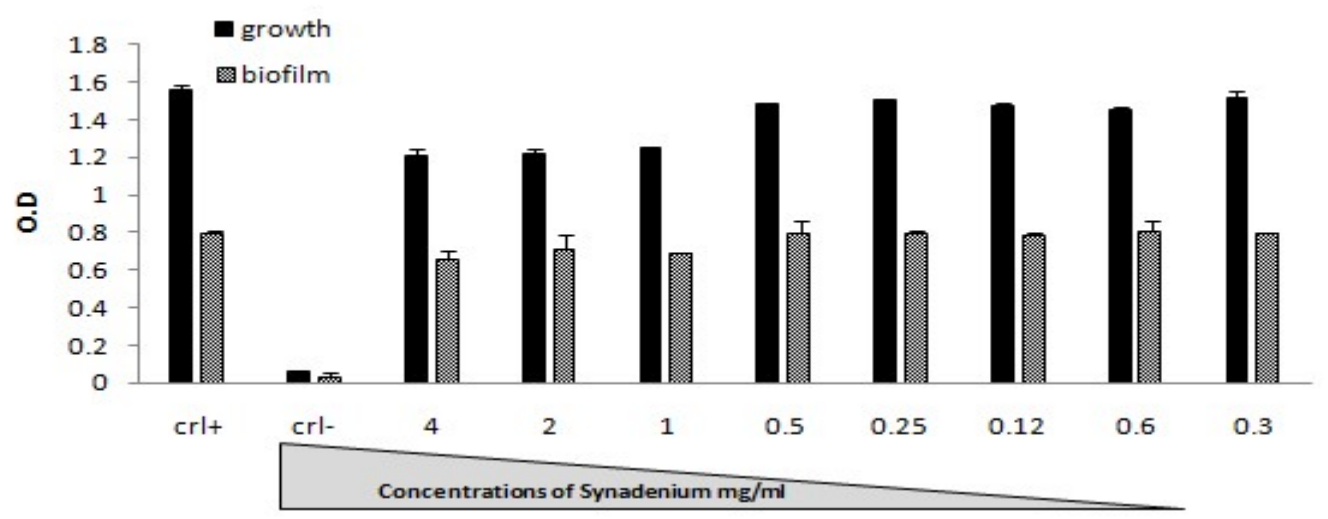

Fig.-5: Antibiofilm of (AM) Extract against p. aurginosa exhibit no activity against Biofilm formationation in concentrations.
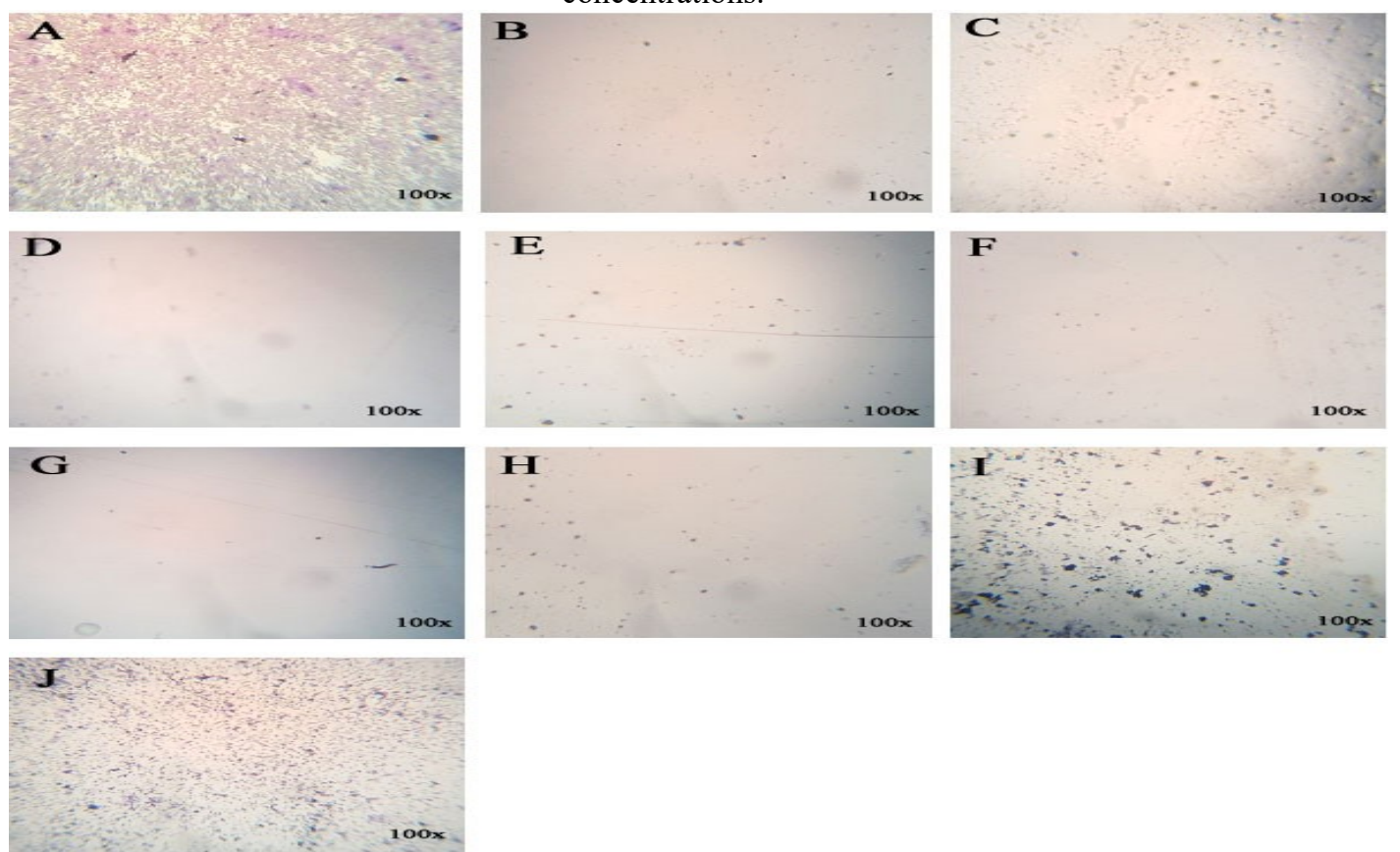

Fig.-6: Microscopic Images 100x of S. aureus biofilm A) represent positive control of $S$. aureus, cells aggregated together with biofilm matrix (B) represent negative control untreated TSB media, Panels (CtoJ) represent of (AM) extract treated samples at concentrations (4 to $0.3 \mathrm{mg} / \mathrm{ml}$ ) respectively which exhibited prevention of biofilm production in a dose-dependent manner.

\section{CONCLUSION}

These data suggest that $S$. grantii aerial parts extract is a very good source as a natural antioxidant, antimicrobial and antibiofilm against bacterial pathogens agent, may be potential in the nutraceutical and pharmaceutical industries after the safety examinations. 
RASĀYAN J. Chem.

Vol. 14 | No. 2 |811-828| April - June | 2021

\section{ACKNOWLEDGEMENT}

The authors would like to thank Dr. M. EL-Gibaly, Lecturer of Taxonomy and Consultant for Central Administration of Plantation and Environment, Egypt; for plants identification and supply.

\section{REFERENCES}

1. A.P. Rogerio, C.R .Cardoso, C .Fontanari, M.A. Souza, S.R. Afonso-Cardoso, EVG. Silva, N.S. Koyama, F.L. Basei, E.G, Soares and J.B. Calixto, Glicobiology, 17, 795(2007), DOI: $10.1093 /$ glycob/cwm053

2. L.I. Zhuan-Hong, G.U.O. Han , X.U. Wen-Bin, G.E. Juan , L.I. Xin , A.L. Mireguli and H.E. , Journal of Chromatographic Science, 54(5), 805(2016), DOI:10.1093/chromsci/bmw016

3. M. George, L. Joseph and Ramaswamy, African Journal of Traditional, Complementary and Alternative Medicines, 6(4), 554(2009), DOI:10.4314/ajtcam.v6i4.57206

4. B. Saranya, T. Sulfikarali, S. Chindhu, A. M. Muneeb, N. K. Leela and T. J. Zachariah, Journal of Spices and Aromatic Crops, 26(1), 9(2017), DOI:10.25081/josac.2017.v26.11.803

5. F. J. Firdaus, N. H. Sami, Soekamtoand J. Latip, Rasayan Journal of Chemistry, 14(2), 676(2021), DOI:10.31788/ RJC.2021.1425976

6. A. Karunanidhi, E. Ghaznavi-Rad, and R. A. Hamat, BioMed Research International, 2018,1(2018), DOI:10.1155/2018/9845075

7. S. E. Desouky, M. S. El-Gamal, A. F. Mohammed, World Applied Sciences Journal, 32, 731(2014), DOI:10.13140/RG.2.1.2311.9768

8. A. Hamed, A. S. Abdel-Razek, M. Araby, M. Abu-Elghait, D.G El-Hosari, M. Frese, H. S. M. Soliman, H. G. Stammler, N. Sewald and M. Shaaban, Natural Product Research, 1-9, (2020), DOI: $10.1080 / 14786419.2020 .1741583$

9. E. Ahmed, W.A. Elkhateeb, H.A.A. Taie, M. Rateb and W. Fayad, Journal of Applied Pharmacutical Science, 7(1), 98(2017), DOI:10.7324/JAPS.2017.70113

10. A.S.A. Elkarim, S. Abdelaziz, H.G. Attia, H.A.A. Taie and R. Monir, Pharmacognosy Journal, 12(6), 1421(2020), DOI:10.5530/pj.2020.12.196

11. M.B. Hossaina, N.P. Bruntonb , C. Barry-Ryana , A.B. Martin-Dianaa , and M. Wilkinsonc, Rasayan Journl of Chemistry, l(4), 751(2008).

12. H.A.A. Taie, H.I. Abd-Alla, S.A. Ali and H.F. Aly, International Journal of Pharmacy and Pharmaceutical Sciences, 7(6), 311(2015).

13. Clinical and Laboratory Standards Institute Performance Standards for Antimicrobial Susceptibility Testing, Twenty-fifth Informational Supplement, CLSI Document, M100-S29, Wayne, Pa, USA. 2019.

14. K. R. C.Goly, Y. Soro, A. Dadie, A. B. B. Kassi and D. J. E. Marcellin , Rasayan Journal of Chemistry, 8(4), 396(2015).

15. Y.Yinjun, S. Xinguang, L. Jinjun, L. Kang, S. Chen, B. Ma and B. Guo, Molecules, 21(10), 1306(2016), DOI:10.3390/molecules21101307

16. N. Fabre, I. Rustan, E. Hoffmann and J. Quetin-Leclercq, Journal of the American Society for Mass Spectrometry, 12(6), 707(2001), DOI:10.1016/S1044-0305(01)00226-4

17. I.M. Abu-Reidah, D. Arráez-Román, A. Segura-Carretero, and A. Fernández-Gutiérrez, Food Research International Journal, 51, 354(2013), DOI:10.1016/J.FOODRES.2012.12.033

18. B. Anghel, E. R. Javier, A. Carlos, B. Sepúlveda and, M. J. Simirgiotis, Molecules, 19(11), 17400(2014), DOI:10.3390/molecules191117400

19. I.M. Abu-Reidah, S. A. Mohammed, M. J. Rana and A. Segura-carretero, Food Chemistry, 166, 179(2015), DOI:10.1016/j.foodchem.2014.06.011

20. D. Ivayla, B. Ilian, k.Violeta, P. Dobson , G. Mcdougall and D. Stewart, International Journal of Agriculture Science and Research, 3(3), 127(2013).

21. L. Regazzoni, E. Arlandini, D. Garzon, N. A. Santagati, , G . Beretta and M. R. Facino, Journal of Pharmacutical and Biomedical Analysis, 72, 202(2013), DOI:10.1016/j.jpba.2012.08.017

22. M. M. Shabana, A. M. El Sayed and M. F. Yousif, Pharmacognosy Magazin, 7, 298(2011), 
RASĀYAN J. Chem.

Vol. 14 | No. 2 |811-828| April - June | 2021

DOI:10.1016/J.FOODCHEM.2014.06.011

23. P. Kachlicki, A. Piasecka, M. Stobiecki and T. Marczak, Molecules, 19(11), 17400(2014), DOI: $10.3390 /$ molecules21111494

24. H. Rini , M. Lamek, I.A. Ketut and S. Partomuan, Rasayan Journal of Chemistry, 12(3), 1822(2019), DOI:10.31788/RJC.2019.1235353

25. C. Yeqing, Y. U. Hongli, W. U, Hao, P. Yaozong Pan, W. Kuilong, J.I.N. Yangping Jin and Z. Chengchao. Molecules, 20(10), 18352(2015), DOI:10.3390/molecules201018352

26. S. Sabina, L. Dae-Young, P. Ji-Hae, C. Jin-Gyeong S. Woo-Duck, K. Hee Cheol, J. Yong-Jin Y. Seung-Woo , B, Myun-Ho and B, Journal of the Korean Society for Applied Biological Chemistry, 55, 689(2012), DOI:10.1007/s13765-012-2133-2

27. R. Perestrelo, Y. Lu, S. A. O. Santos, A. J. D. Silvestre, C. P. Neto, J. S. Câmara and S. M. Rocha, Food Chemistry, 135, 94(2012), DOI:10.1016/j.foodchem.2012.04.102

28. H. Mcnab, E.S.B. Ferreira, A.N. Hulmea and A. Quye, International Journal of mass Spectrometry, 284, 57(2009), DOI:10.1016/j.ijms.2008.05.039

29. W. Schänzer, H. Geyer, A. Gotzmann, U Mareck (eds.) Recent Advances in Doping Analysis (14), Sport BuchStrauss Gmbh., Köln, pp. 91-100 (2006).

30 C. W. Kirby, T. Wu, R. Tsao and L. M. C Jason, Phytochemistry, 94, 284(2013), DOI: $10.1016 /$ j.phytochem.2013.06.017

31. S. De Pascual-T, J. C. Rivas-Gonzalo, The Royal Society of Chemistry, pp.48-62(2003).

32. P. Monique, V.S Christine, P. Konstantinos, E. Claire, S. Jean-Paul, M. Aymeric and B. Denis, Rapid Communication in Mass Spectrometry, 17(12), 1297(2003), DOI:10.1002/rcm. 1054

33. H.Q. Zhao, X.Wang, H.M. Li, B. Yang, H.J. Yang, and L. Huang, Molecules. 18(8), 9755(2013), DOI: $10.3390 /$ molecules 18089755

34. W. Zhijun, W. Xiaowei, M. Chen, C. Mo, H. U Hongyan, C. Jie, C.Tuanyao and W. Hong, Molecules. 24(6), 1058(2019), DOI:10.3390/molecules2406105

35. M. Sanz, E. Cadahía, , E. Esteruelas, A.M. Muñoz, S.B. Fernandez de, T. Hernandez, and I. Estrella, Journal of Agriculture and Food Chemistry, 58(17),9631(2010), DOI:10.1021/JF102718T

36. B. Fröhlich, R. Niemetz, G. G. Gross, Gallotannin, Planta Medica, 216(1), 168(2002), DOI: $10.1021 /$ jf102718t .

37. H. Matsuda, T. Ohta, A. Kawaguchi and M. Yoshikawa, Chemical and Pharmacutical Bulletin, 49(1), 69(2001), DOI:10.1248/cpb.49.69

38. N.P. Dasari, B.G Rao, E.S Rao, T.M Rao and V.S. Praneeth, Free Radicals Antioxidants, 2(2), 68(2012), DOI:10.5530/ax.2012.2.12

39. I. Gülçin, Innovative Food Science and Emerging Technologies, 11, 210(2010), DOI: $10.1016 /$ j.ifset.2009.07.002

40. A.C. Munhoz, B. R.Minozoo, L. S. Cruz, T. L. Oliveira, W. M. Machado, A.V Pereira, D. Fernandes, F. A. Manente, J. C. Vellosa, A. Nepel and A. Barison. Oliveria, Planta Medica, 80(06), 458(2014), DOI:10.1055/s-0034-1368300

41. S.Kumar, A. Mishra and A. K. Pandey, BMC Complementary and Alternative Medicine, 13(1),120 (2013), DOI: 10.1186/1472-6882-13-120

[RJC-6165/2020] 